\title{
Ensemble-based satellite-derived carbon dioxide and methane column-averaged dry-air mole fraction data sets (2003-2018) for carbon and climate applications
}

\author{
Maximilian Reuter ${ }^{1}$, Michael Buchwitz ${ }^{1}$, Oliver Schneising ${ }^{1}$, Stefan Noël ${ }^{1}$, Heinrich Bovensmann ${ }^{1}$, John P. Burrows ${ }^{1}$, \\ Hartmut Boesch ${ }^{2,3}$, Antonio Di Noia ${ }^{2,3}$, Jasdeep Anand ${ }^{2,3}$, Robert J. Parker ${ }^{2,3}$, Peter Somkuti ${ }^{2,3,8}$, Lianghai Wu ${ }^{4}$, \\ Otto P. Hasekamp ${ }^{4}$, Ilse Aben ${ }^{4}$, Akihiko Kuze ${ }^{5}$, Hiroshi Suto ${ }^{5}$, Kei Shiomi ${ }^{5}$, Yukio Yoshida ${ }^{6}$, Isamu Morino ${ }^{6}$, \\ David Crisp $^{7}$, Christopher W. O'Dell ${ }^{8}$, Justus Notholt ${ }^{1}$, Christof Petri ${ }^{1}$, Thorsten Warneke $^{1}$, Voltaire A. Velazco ${ }^{9}$, \\ Nicholas M. Deutscher ${ }^{9}$, David W. T. Griffith ${ }^{9}$, Rigel Kivi ${ }^{10}$, David F. Pollard ${ }^{11}$, Frank Hase ${ }^{12}$, Ralf Sussmann ${ }^{13}$, \\ Yao V. Té ${ }^{14}$, Kimberly Strong ${ }^{15}$, Sébastien Roche ${ }^{15}$, Mahesh K. Sha ${ }^{16}$, Martine De Mazière ${ }^{16}$, Dietrich G. Feist ${ }^{17,18,19}$, \\ Laura T. Iraci ${ }^{20}$, Coleen M. Roehl ${ }^{21}$, Christian Retscher ${ }^{22}$, and Dinand Schepers ${ }^{23}$ \\ ${ }^{1}$ Institute of Environmental Physics (IUP), University of Bremen, 28334 Bremen, Germany \\ ${ }^{2}$ Earth Observation Science, University of Leicester, LE1 7RH, Leicester, UK \\ ${ }^{3}$ NERC National Centre for Earth Observation, LE1 7RH, Leicester, UK \\ ${ }^{4}$ SRON Netherlands Institute for Space Research, 3584 CA Utrecht, the Netherlands \\ ${ }^{5}$ Japan Aerospace Exploration Agency (JAXA), 305-8505, Tsukuba, Japan \\ ${ }^{6}$ National Institute for Environmental Studies (NIES), 305-8506, Tsukuba, Japan \\ ${ }^{7}$ Jet Propulsion Laboratory (JPL), Pasadena, CA 91109, USA \\ ${ }^{8}$ Cooperative Institute for Research in the Atmosphere, Colorado State University (CSU), Fort Collins, CO 80523, USA \\ ${ }^{9}$ Centre for Atmospheric Chemistry, School of Earth, Atmospheric and Life Sciences, \\ University of Wollongong, NSW, 2522, Australia \\ ${ }^{10}$ Space and Earth Observation Centre, Finnish Meteorological Institute (FMI), 99600 Sodankylä, Finland \\ ${ }^{11}$ National Institute of Water and Atmospheric Research (NIWA), Lauder, New Zealand \\ ${ }^{12}$ Karlsruhe Institute of Technology (KIT), Institute of Meteorology and Climate Research (IMK), \\ IMK-ASF, 76021 Karlsruhe, Germany \\ ${ }^{13}$ Karlsruhe Institute of Technology (KIT), Institute of Meteorology and Climate Research (IMK), \\ IMK-IFU, 82467 Garmisch-Partenkirchen, Germany \\ ${ }^{14}$ Laboratoire d'Etudes du Rayonnement et de la Matière en Astrophysique et Atmosphéres (LERMA-IPSL), \\ Sorbonne Université, CNRS, Observatoire de Paris, PSL Université, 75005 Paris, France \\ ${ }^{15}$ Department of Physics, University of Toronto, Toronto, ON, M5S 1A7, Canada \\ ${ }^{16}$ Royal Belgian Institute for Space Aeronomy (BIRA-IASB), 1180 Brussels, Belgium \\ ${ }^{17}$ Max Planck Institute for Biogeochemistry, 07745 Jena, Germany \\ ${ }^{18}$ Lehrstuhl für Physik der Atmosphäre, Ludwig-Maximilians-Universität München, 80333 Munich, Germany \\ ${ }^{19}$ Institut für Physik der Atmosphäre, Deutsches Zentrum für Luft- und Raumfahrt Oberpfaffenhofen, \\ 82234 Weßling, Germany \\ ${ }^{20}$ Atmospheric Science Branch, National Aeronautics and Space Administration (NASA), Moffett Field, CA 94035, USA \\ ${ }^{21}$ California Institute of Technology, Pasadena, CA 91125, USA \\ ${ }^{22}$ Directorate of Earth Observation Programmes, European Space Agency (ESA), ESRIN, 00044 Frascati, Italy \\ ${ }^{23}$ European Centre for Medium-Range Weather Forecasts (ECMWF), Reading RG2 9AX, UK
}

Correspondence: Michael Buchwitz (buchwitz@uni-bremen.de)

Received: 21 October 2019 - Discussion started: 30 October 2019

Revised: 16 January 2020 - Accepted: 20 January 2020 - Published: 19 February 2020

Published by Copernicus Publications on behalf of the European Geosciences Union. 
Abstract. Satellite retrievals of column-averaged dry-air mole fractions of carbon dioxide $\left(\mathrm{CO}_{2}\right)$ and methane $\left(\mathrm{CH}_{4}\right)$, denoted $\mathrm{XCO}_{2}$ and $\mathrm{XCH}_{4}$, respectively, have been used in recent years to obtain information on natural and anthropogenic sources and sinks and for other applications such as comparisons with climate models. Here we present new data sets based on merging several individual satellite data products in order to generate consistent long-term climate data records (CDRs) of these two Essential Climate Variables (ECVs). These ECV CDRs, which cover the time period 2003-2018, have been generated using an ensemble of data products from the satellite sensors SCIAMACHY/ENVISAT and TANSO-FTS/GOSAT and (for $\mathrm{XCO}_{2}$ ) for the first time also including data from the Orbiting Carbon Observatory 2 (OCO-2) satellite. Two types of products have been generated: (i) Level 2 (L2) products generated with the latest version of the ensemble median algorithm (EMMA) and (ii) Level 3 (L3) products obtained by gridding the corresponding L2 EMMA products to obtain a monthly $5^{\circ} \times 5^{\circ}$ data product in Obs4MIPs (Observations for Model Intercomparisons Project) format. The L2 products consist of daily NetCDF (Network Common Data Form) files, which contain in addition to the main parameters, i.e., $\mathrm{XCO}_{2}$ or $\mathrm{XCH}_{4}$, corresponding uncertainty estimates for random and potential systematic uncertainties and the averaging kernel for each single (quality-filtered) satellite observation. We describe the algorithms used to generate these data products and present quality assessment results based on comparisons with Total Carbon Column Observing Network (TC$\mathrm{CON}$ ) ground-based retrievals. We found that the $\mathrm{XCO}_{2}$ Level 2 data set at the TCCON validation sites can be characterized by the following figures of merit (the corresponding values for the Level 3 product are listed in brackets) single-observation random error $(1 \sigma): 1.29 \mathrm{ppm}$ (monthly: $1.18 \mathrm{ppm}$ ); global bias: $0.20 \mathrm{ppm}(0.18 \mathrm{ppm})$; and spatiotemporal bias or relative accuracy $(1 \sigma)$ : $0.66 \mathrm{ppm}(0.70 \mathrm{ppm})$. The corresponding values for the $\mathrm{XCH}_{4}$ products are singleobservation random error $(1 \sigma)$ : $17.4 \mathrm{ppb}$ (monthly: $8.7 \mathrm{ppb}$ ); global bias: $-2.0 \mathrm{ppb}(-2.9 \mathrm{ppb})$; and spatiotemporal bias $(1 \sigma): 5.0 \mathrm{ppb}(4.9 \mathrm{ppb})$. It has also been found that the data products exhibit very good long-term stability as no significant long-term bias trend has been identified. The new data sets have also been used to derive annual $\mathrm{XCO}_{2}$ and $\mathrm{XCH}_{4}$ growth rates, which are in reasonable to good agreement with growth rates from the National Oceanic and Atmospheric Administration (NOAA) based on marine surface observations. The presented ECV data sets are available (from early 2020 onwards) via the Climate Data Store (CDS, https://cds.climate.copernicus.eu/, last access: 10 January 2020) of the Copernicus Climate Change Service (C3S, https://climate.copernicus.eu/, last access: 10 January 2020).

\section{Introduction}

Carbon dioxide $\left(\mathrm{CO}_{2}\right)$ and methane $\left(\mathrm{CH}_{4}\right)$ are important greenhouse gases and increasing atmospheric concentrations result in global warming with adverse consequences such as sea level rise (IPCC, 2013). Because of their importance for climate, these gases have been classified as Essential Climate Variables (ECVs) by the Global Climate Observing System (GCOS) (GCOS-154, 2010; GCOS-200, 2016). The generation of $\mathrm{XCO}_{2}$ and $\mathrm{XCH}_{4}$ satellite-derived ECV data products meeting GCOS requirements using European satellite retrieval algorithms started in 2010 in the framework of the GHG-CCI project (http://www.esa-ghg-cci.org/, last access: 10 January 2020) of the European Space Agency's (ESA) Climate Change Initiative (CCI) (Hollmann et al., 2013). Since the end of 2016, this activity continues operationally via the Copernicus Climate Change Service (C3S, https://climate.copernicus.eu/, last access: 10 January 2020), and the corresponding $\mathrm{CO}_{2}$ and $\mathrm{CH}_{4}$ data products are available via the Copernicus Climate Data Store (CDS, https: //cds.climate.copernicus.eu/, last access: 10 January 2020). These ECV data products have been used for a range of applications such as improving our knowledge of $\mathrm{CO}_{2}$ and/or $\mathrm{CH}_{4}$ surface fluxes (e.g., Alexe et al., 2015; Basu et al., 2013; Buchwitz et al., 2017a; Chevallier et al., 2014, 2015; Ganesan et al., 2017; Gaubert et al., 2019; Houweling et al., 2015; Liu et al., 2017; Maasakkers et al., 2019; Miller et al., 2019; Reuter et al., 2014a, b, 2019a; Sheng et al., 2018; Schneising et al., 2014b; Turner et al., 2015, 2019), comparison with climate and other models (e.g., Hayman et al., 2014; Lauer et al., 2017; Schneising et al., 2014a), and for other applications such as computation of $\mathrm{CO}_{2}$ growth rates (e.g., Buchwitz et al., 2018), as well as to better understand changes in the amplitude of the $\mathrm{CO}_{2}$ seasonal cycle (e.g., Yin et al., 2018).

The C3S satellite greenhouse gas (GHG) data set consists of single-sensor satellite data products and of merged (i.e., combined multi-sensor, multi-algorithm) data products. Here we present the latest version, version 4.1, of the merged Level 2 (L2) and merged Level 3 (L3) $\mathrm{XCO}_{2}$ and $\mathrm{XCH}_{4}$ data products, which cover the time period 2003-2018. The L2 products (XCO2_EMMA and XCH4_EMMA) have been compiled with the ensemble median algorithm (EMMA) originally proposed by Reuter et al. (2013) and recent modifications, which are described in Sect. 3.1. These products contain detailed information for each single observation (i.e., footprint or ground pixel) including time, latitude and longitude, the main parameter (i.e., $\mathrm{XCO}_{2}$ or $\mathrm{XCH}_{4}$ ), its stochastic uncertainty (e.g., due to instrument noise), an estimate of potential systematic uncertainties (e.g., due to spatial or temporal bias patterns), and its averaging kernel and corresponding a priori profile. The L3 products (XCO2_OBS4MIPS and XCH4_OBS4MIPS) are gridded products at monthly time and $5^{\circ} \times 5^{\circ}$ spatial resolution in Obs4MIPs (Obser- 


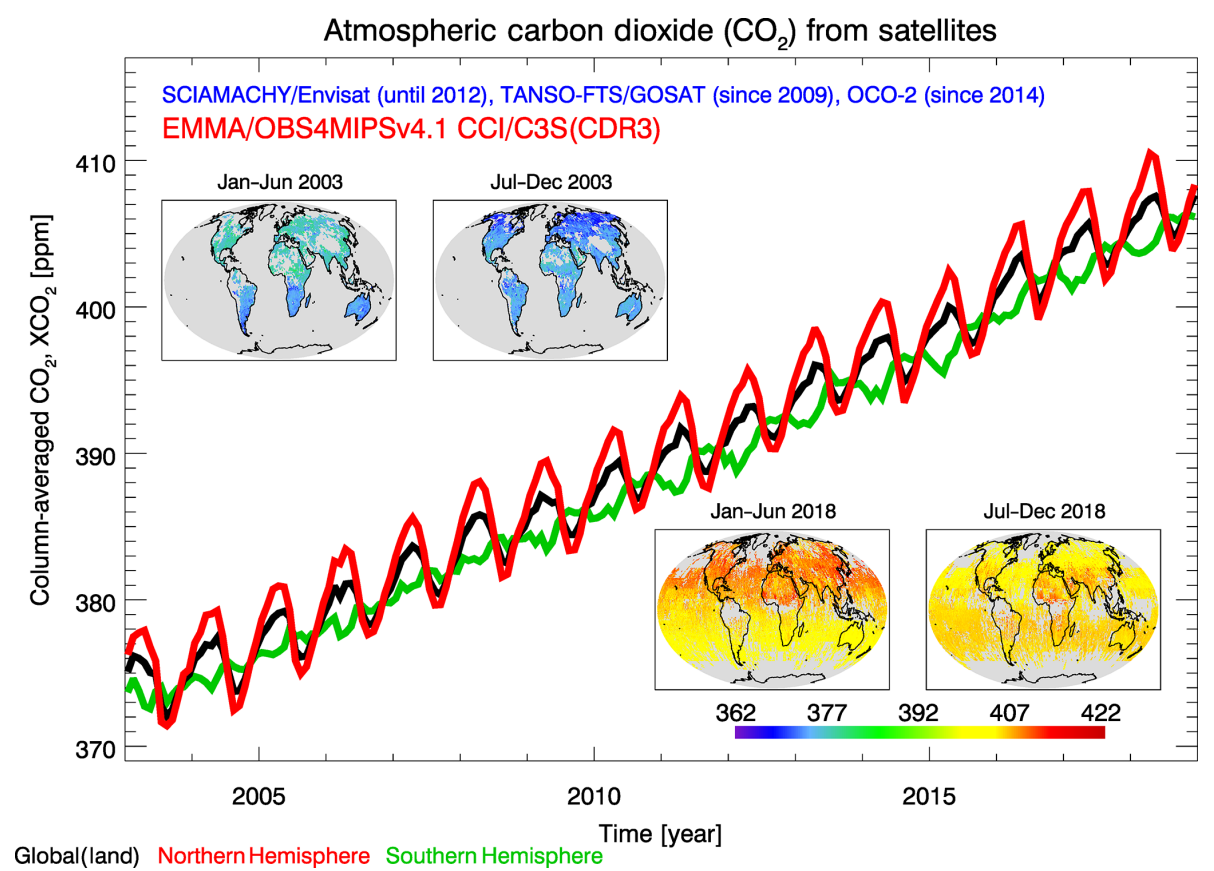

Figure 1. Overview of the presented $\mathrm{XCO}_{2}$ data set. Shown are time series over land for three latitude bands (global, black line; Northern Hemisphere, red; Southern Hemisphere, green) and global maps (half-yearly averages at $1^{\circ} \times 1^{\circ}$ obtained by gridding (averaging) the merged Level 2, i.e., EMMA, product). See Sect. 4 for a detailed discussion.

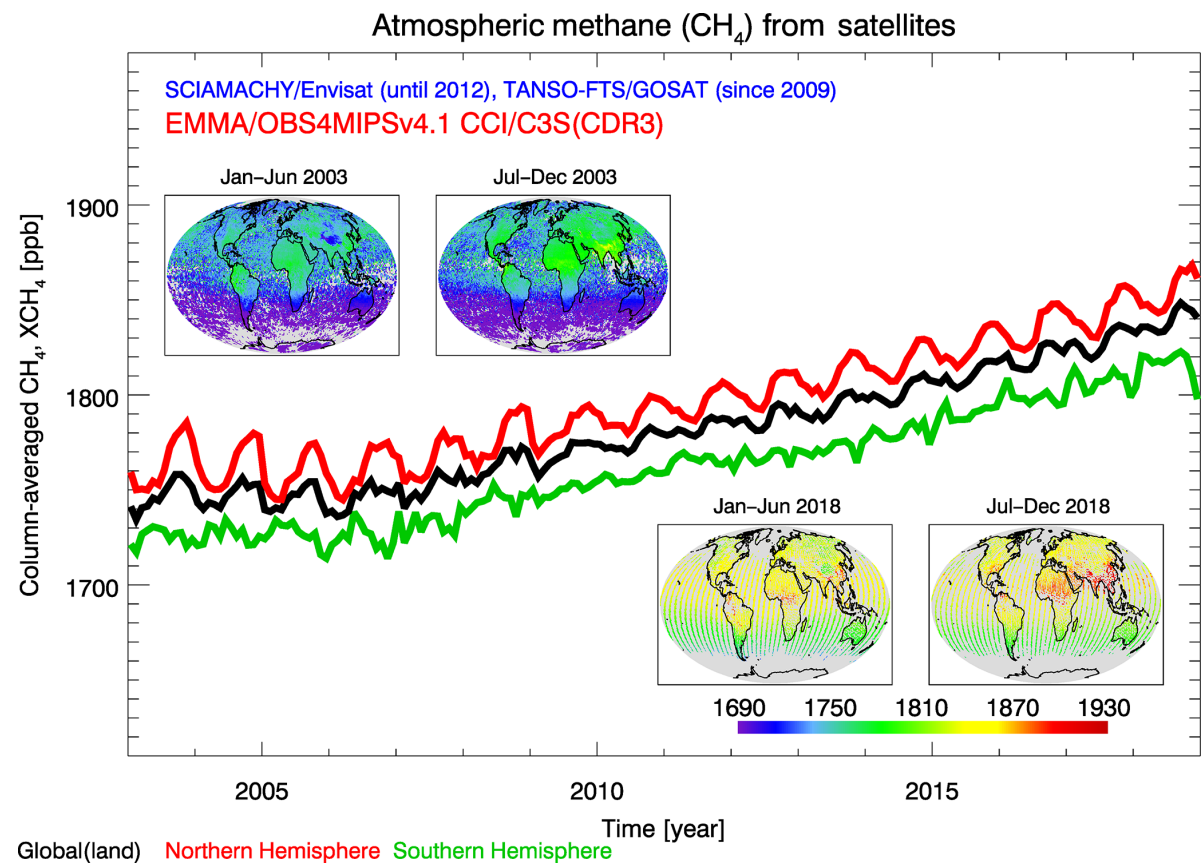

Figure 2. As Fig. 1 but for $\mathrm{XCH}_{4}$.

vations for Model Intercomparisons Project, https://www. earthsystemcog.org/projects/obs4mips/, last access: 10 January 2020) format.

Figure 1 provides an overview of the resulting merged $\mathrm{XCO}_{2}$ data product in terms of time series for three latitude bands and global maps and the similarly structured Fig. 2 shows the $\mathrm{XCH}_{4}$ product. As can be seen, $\mathrm{XCO}_{2}$ and $\mathrm{XCH}_{4}$ are both increasing with time and exhibit seasonal fluctuations and spatial variations. The spatiotemporal characteristics of the merged data - e.g., the spatial sampling - reflect 
the characteristics of the underlying individual sensor satellite data (described in the data section, Sect. 2). Figures 1 and 2 are discussed in detail in the results section, Sect. 4. How these data products have been generated is described in the methods section, Sect. 3. A summary and conclusions are given in Sect. 5.

\section{Data}

In this section, we present an overview about the input data used to generate and validate the new $\mathrm{XCO}_{2}$ and $\mathrm{XCH}_{4}$ data products.

\subsection{Satellite data}

The input satellite data used to generate the merged satellite data products are individual satellite sensor Level 2 (L2) data products. Table 1 provides an overview about the satellite $\mathrm{XCO}_{2}$ input data sets. As can be seen, in total eight $\mathrm{XCO}_{2}$ $\mathrm{L} 2$ data products have been used to generate the merged $\mathrm{L} 2$ and Level 3 (L3) $\mathrm{XCO}_{2}$ data products, each corresponding to a different combination of satellite sensor and retrieval algorithm. An overview about the time coverage of these input data products is presented in Fig. 3. As can be seen, the time period 2003 to March 2009 is only covered by one $\mathrm{XCO}_{2}$ product, namely $\mathrm{XCO}_{2}$ retrieved with the Bremen Optimal Estimation DOAS (BESD) algorithm (Reuter et al., 2010, 2011) from the SCIAMACHY/ENVISAT (Bovensmann et al., 1999) instrument. A second SCIAMACHY $\mathrm{XCO}_{2}$ data product is available, which has been retrieved with the Weighting Function Modified Differential Optical Absorption Spectroscopy (WFM-DOAS or WFMD) algorithm (Schneising et al., 2011), but this product is not used because the merging algorithm EMMA (Reuter et al., 2013, described in Sect. 3.1) requires one or more than two input data products (because the median of a set of elements is, according to our definition which avoids averaging, not defined for two elements). Therefore, one of the two products had to be selected, and the choice was the BESD product for $\mathrm{XCO}_{2}$ because of somewhat higher data quality compared to the WFMD product (Buchwitz et al., 2017b) (note however that the WFMD product has the advantage of containing a larger number of observations). As can be seen from Table 1 and Fig. 3, several GOSAT input products have been used from April 2009 onwards and two OCO-2 $\mathrm{XCO}_{2}$ products from September 2014 and May 2015 onwards. Note that additional algorithms/data products are available but have not been used as input, for example the GOSAT BESD $\mathrm{XCO}_{2}$ product (Heymann et al., 2015) and the OCO-2 RemoTeC $\mathrm{XCO}_{2}$ product (Wu et al., 2018). These or other additional products may be added in future versions of the merged $\mathrm{XCO}_{2}$ products. Note also that we always use the bias-corrected version of a data product, if available (some product files contain bias-corrected and uncorrected values).

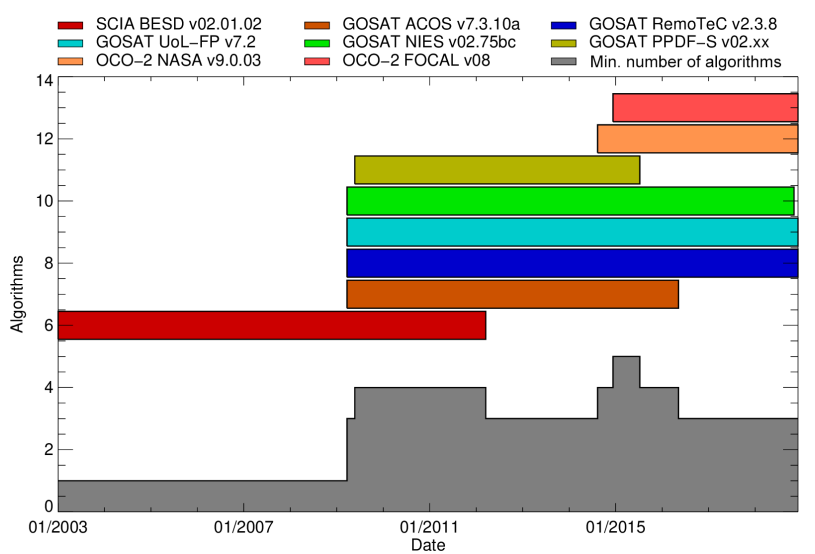

Figure 3. Individual satellite sensor $\mathrm{XCO}_{2}$ data products contributing to the merged $\mathrm{XCO}_{2}$ data products (see Table 1 for details). The required minimum number of contributing products is shown by the grey area.

All listed satellites perform nadir (down-looking) and glint observations and provide radiance spectra covering the relevant $\mathrm{CO}_{2}$ and $\mathrm{CH}_{4}$ absorption bands located in the shortwave infrared (SWIR) part of the electromagnetic spectrum (around 1.6 and $2 \mu \mathrm{m}$ ) and also cover the $\mathrm{O}_{2}$ A-band spectral region in the near-infrared (NIR, around $0.76 \mu \mathrm{m}$ ). All individual sensor input L2 data products have been generated using retrieval algorithms based on minimizing the difference between a modeled radiance spectrum and the observed spectrum by modifying so-called state vector elements (for details we refer to the references listed in Table 1; for additional information see also the Algorithm Theoretical Basis Documents (ATBDs); Buchwitz et al., 2019b, and Reuter et al., 2019b). The exact definition of the state vector depends on the algorithm, but the general approach is based on the optimal estimation (Rodgers, 2000) formalism or similar approaches (see references in Table 1). Among the state vector elements is a representation of the $\mathrm{CO}_{2}$ vertical profile but also other parameters to consider interfering gases (e.g., water vapor), surface reflection, atmospheric scattering, and other effects and parameters, which have an impact on the (interpretation of the) measured radiance spectrum.

Table 2 and Fig. 4 provide an overview about the satellite $\mathrm{XCH}_{4} \mathrm{~L} 2$ input data sets. As for $\mathrm{XCO}_{2}$, the time period 2003 to March 2009 is only covered by one SCIAMACHY data product. From April 2009 onwards several GOSAT $\mathrm{XCH}_{4}$ products are available (see Table 2 ) and have been used to generate the merged $\mathrm{XCH}_{4}$ data $\mathrm{L} 2$ and $\mathrm{L} 3$ data products. For future updates it is also planned to include $\mathrm{XCH}_{4}$ from the Sentinel-5 Precursor (S5P) satellite (Veefkind et al., 2012), but S5P XCH 4 (Hu et al., 2018; Schneising et al., 2019) has not yet been included as the time period covered by these products is currently quite short (less than 2 years). However, we aim to include $\mathrm{S} 5 \mathrm{P} \mathrm{XCH}_{4}$ for one of the next updates of the merged methane products. 
Table 1. Satellite $\mathrm{XCO}_{2}$ Level 2 (L2) data products used as input for the generation of the merged $\mathrm{L} 2$ and $\mathrm{L} 3 \mathrm{XCO}_{2}$ version 4.1 data products. For products which have been generated in the framework of the CCI and C3S projects the corresponding product ID is listed (the other products are external products, which have been obtained from the corresponding websites; see Acknowledgements). Temporal coverage indicates the time coverage of the input data sets.

\begin{tabular}{|c|c|c|c|c|c|c|}
\hline $\begin{array}{l}\text { Algorithm/ } \\
\text { product } \\
\text { acronym }\end{array}$ & $\begin{array}{l}\text { Algorithm/ } \\
\text { product } \\
\text { version }\end{array}$ & $\begin{array}{l}\mathrm{CCI} / \mathrm{C} 3 \mathrm{~S} \\
\text { product ID }\end{array}$ & Satellite/sensor & $\begin{array}{l}\text { Temporal } \\
\text { coverage }\end{array}$ & Comment & Reference \\
\hline BESD & $\mathrm{v} 02.01 .02$ & CO2_SCI_BESD & SCIAMACHY & $\begin{array}{l}01 / 2003- \\
03 / 2012\end{array}$ & - & Reuter et al. (2011) \\
\hline UoL-FP & v7.2 & CO2_GOS_OCFP & GOSAT & $\begin{array}{l}04 / 2009- \\
12 / 2018\end{array}$ & - & Cogan et al. (2012) \\
\hline RemoTeC & v2.3.8 & CO2_GOS_SRFP & GOSAT & $\begin{array}{l}04 / 2009- \\
12 / 2018\end{array}$ & - & Butz et al. (2011) \\
\hline NIES & $\mathrm{v} 02.75 \mathrm{bc}$ & - & GOSAT & $\begin{array}{l}04 / 2009- \\
11 / 2018\end{array}$ & $\begin{array}{l}\text { Bias-corrected } \\
\text { operational } \\
\text { NIES algorithm }\end{array}$ & Yoshida et al. (2013) \\
\hline PPDF-S & $\mathrm{v} 02$ & - & GOSAT & $\begin{array}{l}06 / 2009- \\
07 / 2015\end{array}$ & - & Bril et al. (2012) \\
\hline $\mathrm{ACOS}$ & v7.3.10a & - & GOSAT & $\begin{array}{l}04 / 2009- \\
05 / 2016\end{array}$ & $\begin{array}{l}\text { NASA ACOS } \\
\text { GOSAT algorithm }\end{array}$ & O'Dell et al. (2012) \\
\hline ACOS & v9.0.03 & - & OCO-2 & $\begin{array}{l}09 / 2014- \\
12 / 2018\end{array}$ & $\begin{array}{l}\text { NASA operational } \\
\text { OCO-2 algorithm }\end{array}$ & $\begin{array}{l}\text { O’Dell et al. (2018) } \\
\text { Kiel et al. (2019) }\end{array}$ \\
\hline FOCAL & $\mathrm{v} 08$ & - & OCO-2 & $\begin{array}{l}01 / 2015- \\
12 / 2018\end{array}$ & - & Reuter et al. $(2017 \mathrm{a}, \mathrm{b})$ \\
\hline
\end{tabular}

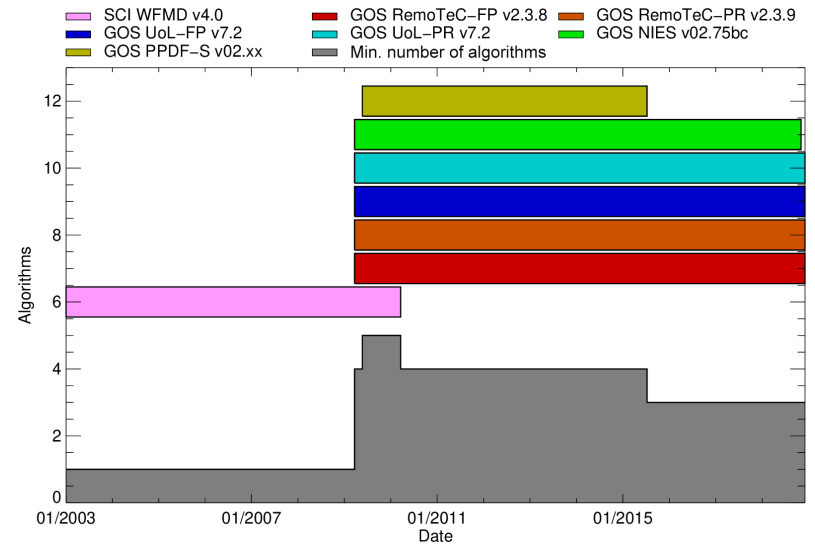

Figure 4. As Fig. 3 but $\mathrm{XCH}_{4}$. For details on each product see Table 2 .

\subsection{Ground-based data}

The satellite data products have been validated by comparison with the $\mathrm{XCO}_{2}$ and $\mathrm{XCH}_{4}$ data products of the TCCON (Wunch et al., 2011). TCCON is a network of ground-based Fourier transform spectrometers (FTSs) recording direct solar spectra in the NIR/SWIR spectral region. From these spectra, accurate and precise column-averaged abundances of $\mathrm{CO}_{2}, \mathrm{CH}_{4}$, and a number of other species are retrieved. The TCCON data products (version GGG2014) have been obtained via the TCCON data archive (https://tccondata.org/, last access: 15 July 2019). An overview about the used TCCON sites is presented in Table 3.

In Sect. 4.3, we present annual $\mathrm{XCO}_{2}$ and $\mathrm{XCH}_{4}$ growth rates, which have been derived from the new $\mathrm{XCO}_{2}$ and $\mathrm{XCH}_{4}$ OBS4MIPS data products using the method described in Buchwitz et al. (2018). These growth rates are compared with growth rates derived from marine surface $\mathrm{CO}_{2}$ and $\mathrm{CH}_{4}$ observations, which have been obtained from the National Oceanic and Atmospheric Administration (NOAA) (for details including links and last access see Acknowledgements).

\section{Methods}

\subsection{Merging algorithm EMMA}

In order to generate the merged L2 products, the ensemble median algorithm is used, which is described in detail in Reuter et al. (2013). Therefore, we limit the description given here to a short overview of the latest version of the EMMA algorithm. To be specific, we initially describe the EMMA $\mathrm{XCO}_{2}$ algorithm and explain differences relevant for $\mathrm{XCH}_{4}$ at the end of this subsection. 
Table 2. As Table 1 but for $\mathrm{XCH}_{4}$.

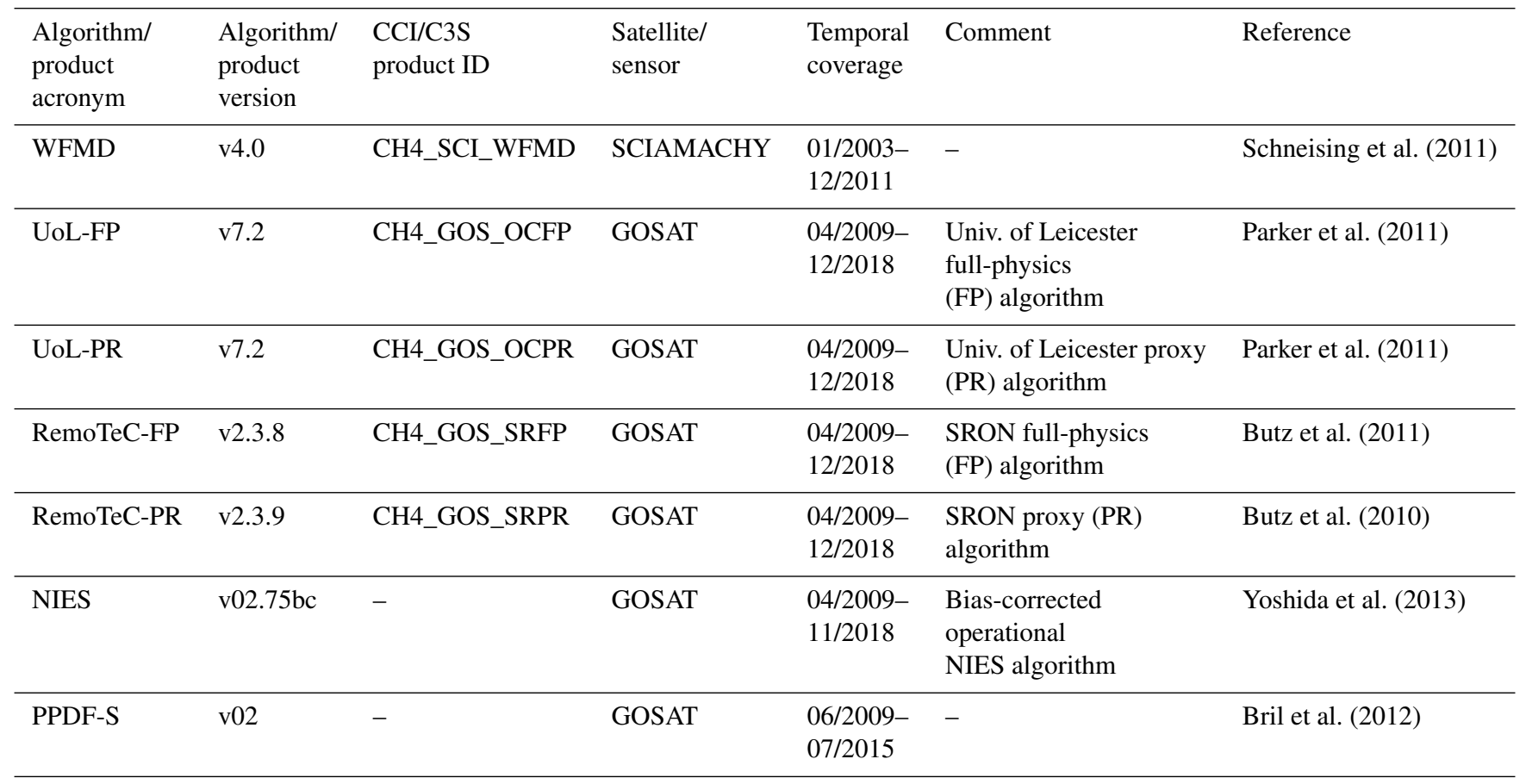

Table 3. TCCON sites used for the validation of the $\mathrm{XCO}_{2}$ and $\mathrm{XCH}_{4}$ satellite-derived data products.

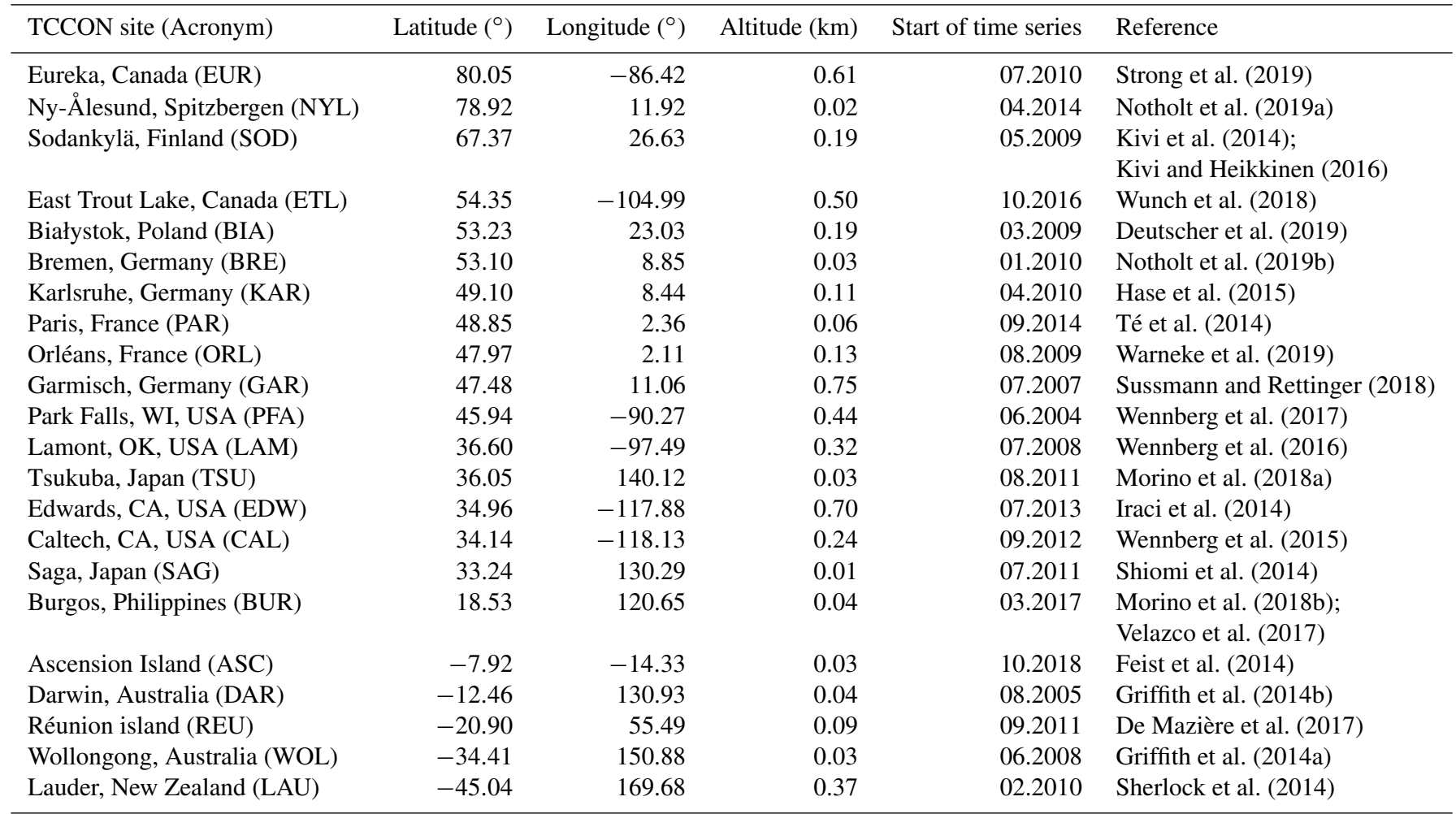


The EMMA $\mathrm{XCO}_{2}$ data product consists of selected individual L2 soundings from the available individual sensor L2 input products (listed in Table 1). The EMMA L2 product is based on selecting the best soundings (i.e., single ground pixel observations) from the ensemble of individual sensor L2 products. Sounding selection is based on monthly time and $10^{\circ} \times 10^{\circ}$ spatial intervals. To decide which individual product is selected for a given month and given grid cell, all input products are first gridded (monthly, $10^{\circ} \times 10^{\circ}$ ) to consider the fact that the spatiotemporal sampling is different for each individual product (due to different satellite sensors and algorithm-dependent quality-filtering strategies). The selected product is the median in terms of average $\mathrm{XCO}_{2}$ per month and grid cell (note that in case of an even number of products the product which is closest to the mean is selected). The median is used primarily to remove potential outliers. The advantage of the median is also (in contrast to, for example, the arithmetic mean) that no averaging or other modifications to the input data are required. In order for a grid cell to be assigned a valid value, the following criterion has to be fulfilled: a minimum number of data products having a standard error of the mean (SEOM) of less than $1 \mathrm{ppm}$ has to be available (see grey area in Fig. 3). SEOM is defined by $\frac{1}{n} \sqrt{\sum_{i} \sigma_{i}^{2}}$, with $\sigma_{i}$ being the (scaled; see below) $\mathrm{XCO}_{2}$ uncertainty of the $i$ th out of $n$ soundings.

This means that EMMA selects for each month and each $10^{\circ} \times 10^{\circ}$ grid cell exactly one product of the available individual L2 input products and then transfers all relevant information (i.e., $\mathrm{XCO}_{2}$ and its uncertainty, related averaging kernels and a priori profile, etc.) from the selected original L2 file into the corresponding daily EMMA L2 product file. This ensures that most of the original information from the selected individual product is also contained in the merged product.

However, some modifications are applied. In order to remove (or at least to minimize) the impact of different a priori assumptions, all products are converted to common a priori $\mathrm{CO}_{2}$ vertical profiles (see Reuter et al., 2013, for details). The new a priori profiles are obtained from the simple empirical $\mathrm{CO}_{2}$ model (SECM, Reuter et al., 2012). SECM is essentially an empirically found function with parameters optimized using a $\mathrm{CO}_{2}$ model (CT2017; see below). The SECM model used here is referred to as SECM2018 and is an update of the SECM model described in Reuter et al. (2012). The main difference is that SECM2018 is using a recent version of NOAA's assimilation system CarbonTracker (Peters et al., 2007, with updates documented at: http://carbontracker.noaa.gov/, last access: 10 January 2020), namely CT2017.

SECM2018 is also used to correct for potential offsets between the individual data products by adding or subtracting a global offset (i.e., by using one constant offset value for each individual product applied globally and for the full time series). Time series of the individual data products before and after offset correction are shown in Fig. 5. Note that in Fig. 5 all data are relative to SECM2018, which is a very simple $\mathrm{CO}_{2}$ model, and therefore all variations and trends seen in Fig. 5 are at least to some extent model errors. As can be seen from Fig. 5, the correction brings the individual data sets typically closer together without changing any of their other characteristics (e.g., their time dependence). But as can also be seen from Fig. 5, better agreement is only achieved on average, not necessarily for all products during the entire time period. For example, the GOSAT RemoTeC product (blue curve) during 2009-2012 exhibits a somewhat larger difference after the offset correction. The approximately $2 \mathrm{ppm}$ $(0.5 \%)$ spike at the beginning of the time series is likely due to a positive bias of the underlying BESD data product, which has not been corrected due to the lack of reference data in this time period (see also the discussion of this aspect in Buchwitz et al., 2018). An obvious issue is also the approximately $1.5 \mathrm{ppm}(0.4 \%)$ discontinuity in the first half of 2014 of the PPDF-S (photon path length probability density function/simultaneous) product (light-green curve). Depending on application, this may be an issue when this product is used stand-alone, but this is not a problem for EMMA as EMMA identifies and ignores outliers.

Another modification applied to the individual L2 input products is a potential scaling of their reported uncertainty for the individual L2 soundings. The scaling factor has been chosen such that on average the uncertainty of the reported error is consistent with the standard deviation of satellite minus ground-based validation data differences (see Sect. 4.1 for the validation of the reported uncertainties via the uncertainty ratio).

In order to avoid that an individual input product, which has much more observations than the other products (such as OCO-2 compared to GOSAT), entirely dominates the EMMA product, a method has been implemented to prevent overweighting the contributions from individual L2 input data products. The method is based on limiting the number of L2 data points. For each grid cell and month, we perform the following steps: first, we compute SEOM for each algorithm. From these values, we compute the 25 th percentile and divide it by $\sqrt{2}$. The result is used as the minimum SEOM threshold. If SEOM of an individual algorithm is smaller than this threshold, a subset of soundings is randomly chosen such that SEOM becomes just larger than the threshold. If, for example, all $\sigma_{i}$ are $1 \mathrm{ppm}$, then SEOM simply becomes $1 / \sqrt{n}$. If in this case, for example, data from four algorithms were available with $n_{1}=60, n_{2}=80, n_{3}=100$, and $n_{4}=1000$, the SEOM threshold would become $1 / \sqrt{2 n_{3}}$, which would effectively limit the number of soundings of the fourth algorithm to 200 (chosen randomly).

In addition to the L2 information of the selected data products, EMMA stores the following diagnostic information for each selected sounding: identifier for the selected L2 algorithm and inter-algorithm spread (IAS) within the grid box of the sounding. Within each grid box, IAS is defined as the 


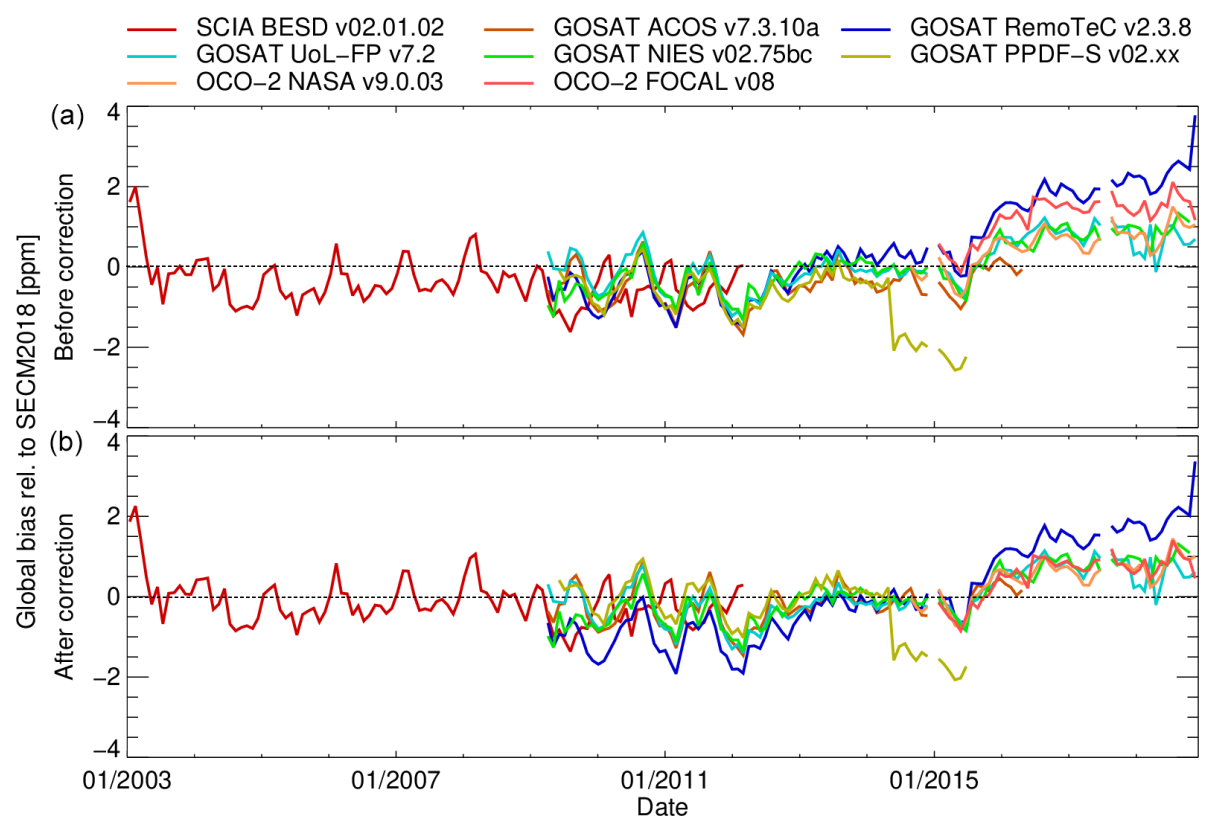

Figure 5. Global bias correction as applied by EMMA to the individual satellite $\mathrm{XCO}_{2}$ input data products. Panel (a) shows the difference relative to the SECM2018 model (computed as satellite - model) before the correction and (b) shows the difference after correction.

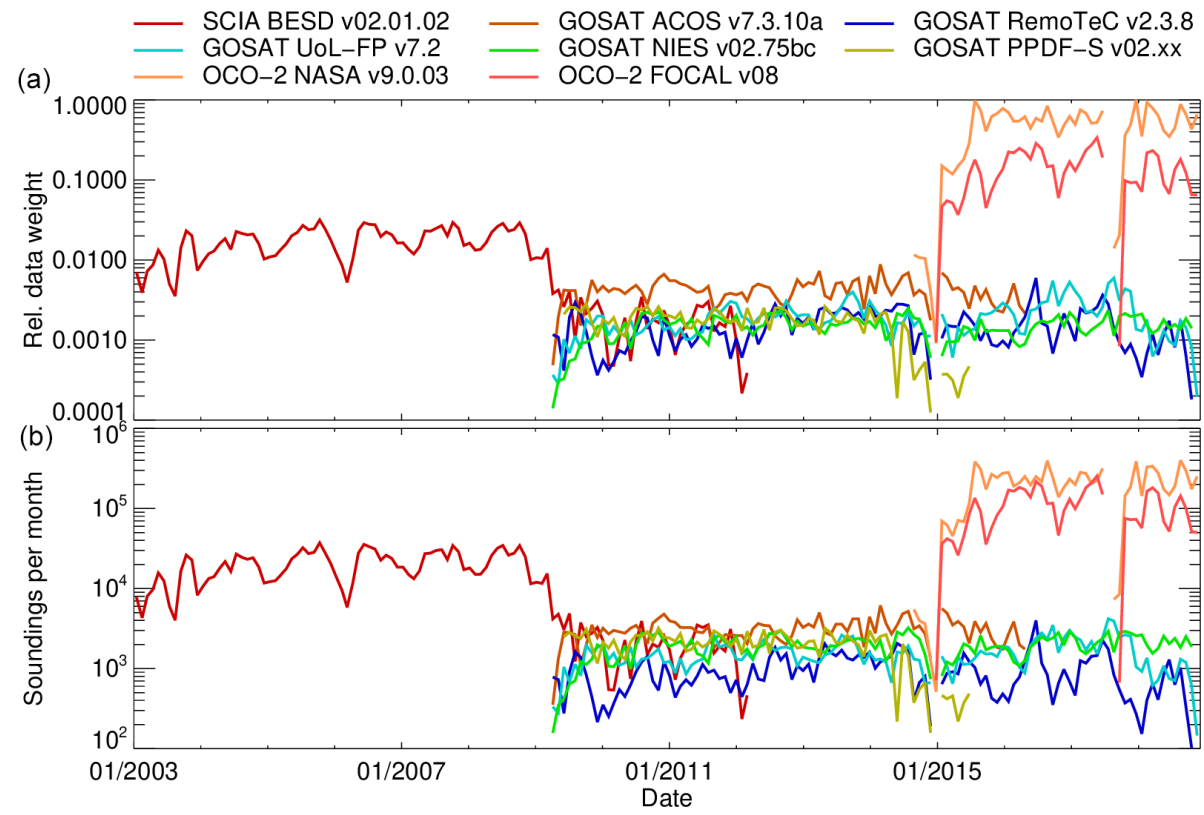

Figure 6. Relative data weight (a) and soundings per month (a) of the individual satellite $\mathrm{XCO}_{2}$ data products contributing to the EMMA $\mathrm{XCO}_{2}$ data product.

algorithm-to-algorithm standard deviation of the grid box averages.

By how much each individual satellite $\mathrm{XCO}_{2}$ data product contributes to the EMMA $\mathrm{XCO}_{2}$ product is shown in Fig. 6. Figure 6a shows the relative data weight (RDW), and Fig. 6b shows the number of soundings per month. How the RDW is defined is explained in detail in Reuter et al. (2013). In short, the RDW is defined as the relative number of soundings weighted with the corresponding (square of the inverse) uncertainty. RDW is high if a (relatively) large number of soundings contribute to the EMMA product and if these soundings have (relatively) low uncertainty compared to the other contributing products. The RDW of a product is a measure of how much information on $\mathrm{XCO}_{2}$ this product con- 
tributes to the EMMA product relative to the other contributing products. As can be seen from Fig. 6, the SCIAMACHY BESD product is the only product until early 2009, when the GOSAT time series starts. As can also be seen, OCO-2 dominates in terms of RDW and number of soundings from 2015 onwards. This is because OCO-2 provides much more data with typically better uncertainty compared to the other (GOSAT) product.

The EMMA L2 $\mathrm{XCH}_{4}$ product has been generated similarly to the EMMA L2 $\mathrm{XCO}_{2}$ product, i.e., using essentially the same method as described above. A difference is that the offset correction has been done with a $\mathrm{CH}_{4}$ model instead of SECM2018. This model is the simple $\mathrm{CH}_{4}$ climatological model (SC4C), and we use the year 2018 update referred to as SC4C2018 in the following. The SC4C2018 model is similar to SECM2018 but for $\mathrm{XCH}_{4}$. It is a model-based $\mathrm{CH}_{4}$ climatology adjusted for the annual growth rate (note that this model has also been used as the climatological training and a calibration data set as described in Schneising et al., 2019). The EMMA algorithm SEOM limit controlling the minimum number of data points per grid box, month, and algorithm has been set to $12 \mathrm{ppb}$ for $\mathrm{XCH}_{4}$. The impact of the offset correction for merging the $\mathrm{XCH}_{4}$ products is shown in Fig. 7. Note that in Fig. 7 all data are relative to SC4C2018, which is a very simple $\mathrm{CH}_{4}$ model, and therefore all variations and trends seen in Fig. 7 are at least to some extent model errors. As for $\mathrm{CO}_{2}$ (Fig. 5) the offset correction typically brings the various $\mathrm{XCH}_{4}$ products closer together but does not change any of their other characteristics. The PPDF-S product suffers from a discontinuity (of $8 \mathrm{ppb}$ or $0.4 \%$ ) in the first half of 2014 (see above for a similar problem for PPDF-S XCO 2 ).

Figure $8 \mathrm{a}$ shows the RDW, and Fig. 8b shows the number of soundings per month for all individual sensor $\mathrm{XCH}_{4}$ products contributing to the $\mathrm{XCH}_{4}$ EMMA product. Until early 2009, the SCIAMACHY WFMD product is the only product contributing to the EMMA product. Note that the RDW of the SCIAMACHY products drops at the end of 2005 (in contrast to the absolute number of soundings per month). The reason is the increase in the uncertainty of this product due to detector degradation (see, e.g., Schneising et al., 2011, for details). As can also be seen, the two GOSAT proxy (PR) products (i.e., CH4_GOS_OCPR and CH4_GOS_SRPR) dominate the $\mathrm{XCH}_{4}$ EMMA product because they contain more soundings compared to the other (GOSAT) data products.

\subsection{Algorithm to generate the Level 3 OBS4MIPS products}

The version 4.1 L3 XCO2_OBS4MIPS and $\mathrm{XCH} 4$ OBS4MIPS data products have been obtained by gridding (averaging) the version 4.1 L2, i.e., XCO2_EMMA and XCH4_EMMA, products using monthly time and $5^{\circ} \times 5^{\circ}$ spatial resolution. The algorithm for the generation of the
OBS4MIPS products is described in Reuter et al. (2019b). Therefore, we here provide only a short overview.

For each individual product, the gridding is based on computing an arithmetic, unweighted average of all soundings falling in a grid box.For each grid box, the standard error of the mean is computed using the uncertainties contained in the corresponding EMMA product files. In order to reduce noise at least two individual observations must be present and the resulting standard error of the mean must be less than $1.6 \mathrm{ppm}$ for $\mathrm{XCO}_{2}$ and less than $12 \mathrm{ppb}$ for $\mathrm{XCH}_{4}$.

Besides $\mathrm{XCO}_{2}$ or $\mathrm{XCH}_{4}$, the final $\mathrm{L} 3$ product also includes (per grid box and month) the number of soundings used for averaging; the average column-averaging kernel; the average a priori profile; the standard deviation of the averaged $\mathrm{XCO}_{2}$ or $\mathrm{XCH}_{4}$ values; and an estimate for the total uncertainty computed as the root sum square of two values, where one value is SEOM and the other value is IAS as computed by EMMA. For cases including only one algorithm, the second value is replaced by quadratically adding spatial and seasonal accuracy determined from the TCCON validation.

\subsection{Validation method}

The validation of the merged satellite-derived $\mathrm{XCO}_{2}$ and $\mathrm{XCH}_{4}$ data products is based on comparisons with groundbased $\mathrm{XCO}_{2}$ and $\mathrm{XCH}_{4}$ TCCON observations (using version GGG2014). We present results from two somewhat different validation methods (the EMMA method, Reuter et al., 2013; and the QA/QC method, Buchwitz et al., 2017b; see below), which are similar to other validation methods used in recent years (e.g., Butz et al., 2010; Cogan et al., 2012; Dils et al., 2014; O'Dell et al., 2018; Parker et al., 2011). These methods differ with respect to details such as the chosen colocation criterion, whether the data are brought to a common a priori or not, and if yes which a priori has been used. In the following, we will highlight some of these details as relevant for the two validation methods used for this paper.

Both methods used for the validation of the L2 EMMA products are based on colocating each individual satellite $\mathrm{XCO}_{2}$ (or $\mathrm{XCH}_{4}$ ) observation with a corresponding value obtained from TCCON using predefined spatial and temporal colocation criteria (see below). The comparisons take into account different a priori assumptions regarding the vertical profiles of $\mathrm{CO}_{2}\left(\right.$ or $\left.\mathrm{CH}_{4}\right)$ as used for the generation of the $\mathrm{L} 2$ input products by converting either the satellite data (QA/QC method) or the TCCON data (EMMA method) to a common a priori. This a priori correction is based on using the satellite averaging kernels and a priori profiles, which are contained (for each single observation) in the EMMA product files. The magnitude of the a priori correction (the explicit formula is shown as Eq. 3 in Dils et al., 2014) depends on the deviation (difference) of the averaging kernel from unity and on the difference of the a priori profiles. Because the averaging kernel profiles are typically close to unity (note that both satellite and the TCCON retrievals correspond to cloud-free 


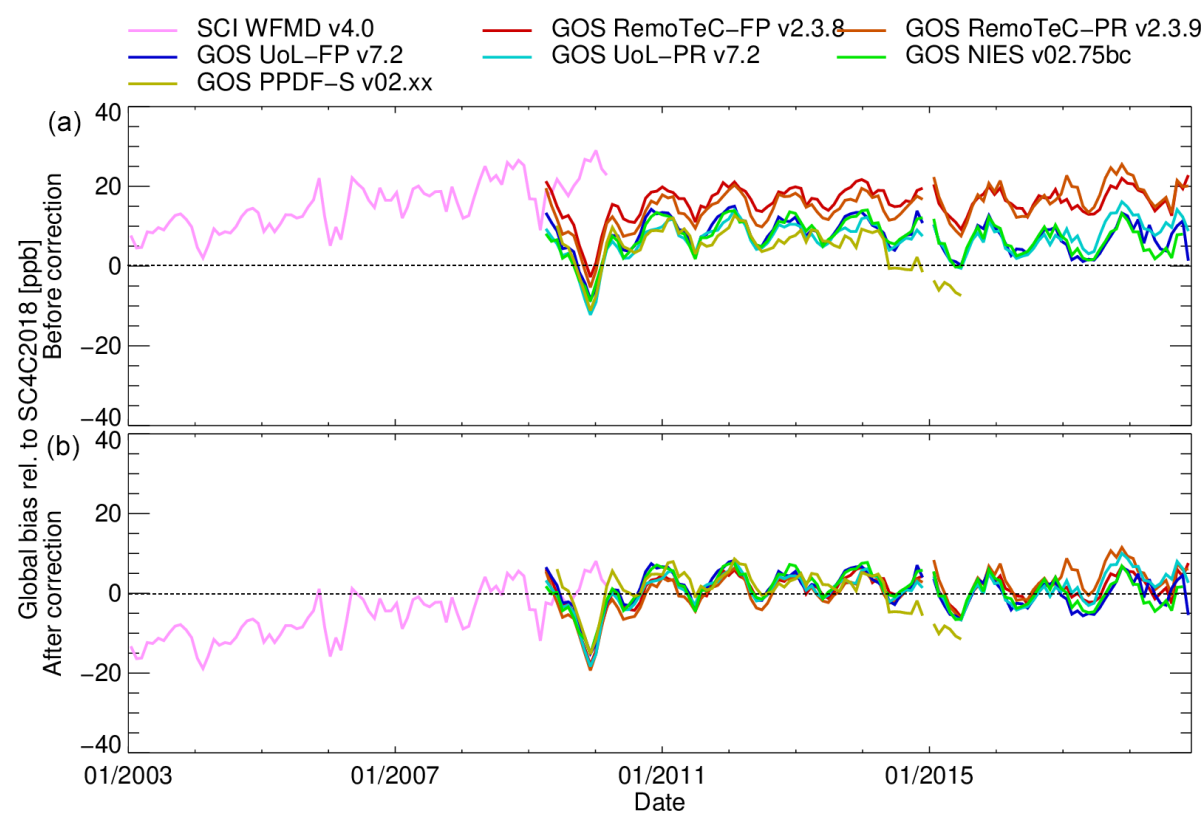

Figure 7. As Fig. 5 but for $\mathrm{XCH}_{4}$ and using methane model SC4C2018.

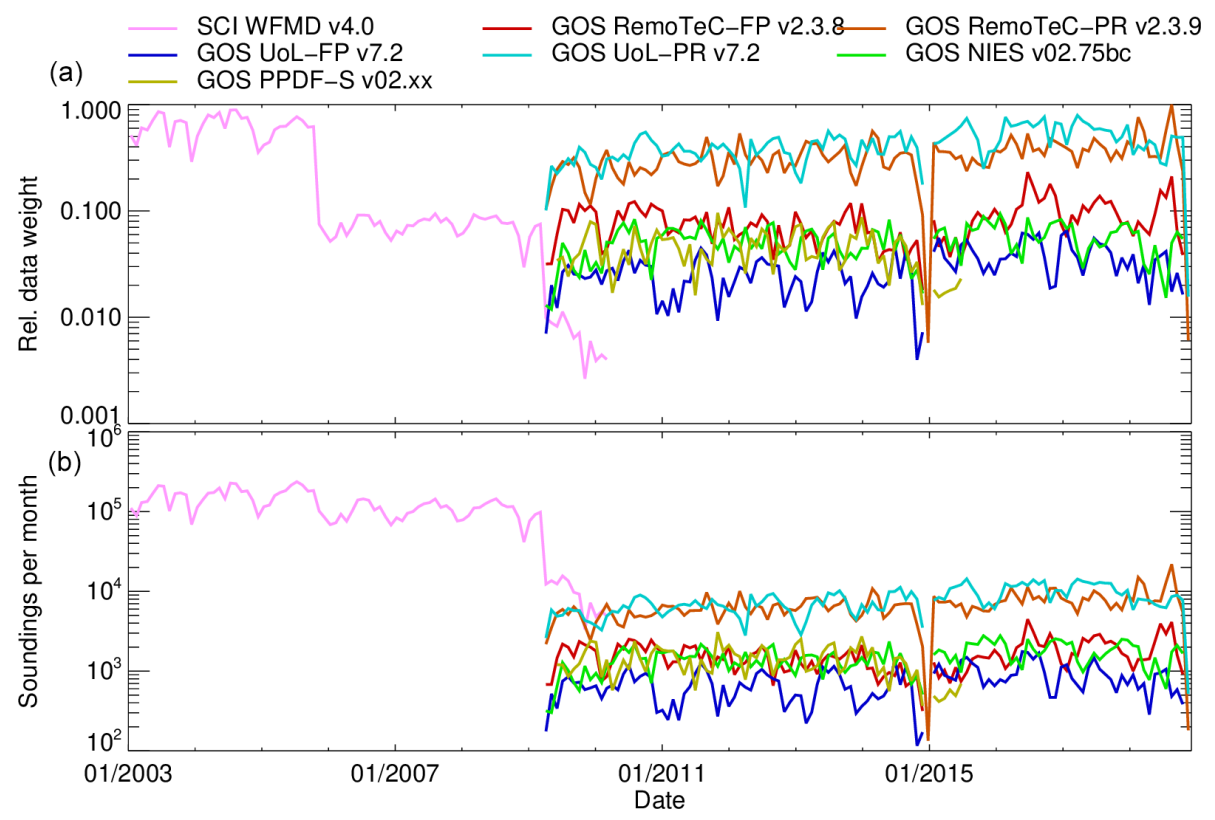

Figure 8. As Fig. 6 but for $\mathrm{XCH}_{4}$.

conditions) and because the a priori profiles are not totally unrealistic, the a priori correction is typically very small (approximately $0.1 \mathrm{ppm}$ for $\mathrm{XCO}_{2}$ and $1 \mathrm{ppb}$ for $\mathrm{XCH}_{4}$ ).

The first validation method is the EMMA quality assessment method, which is described in Reuter et al. (2013). Note that EMMA is not only a merging method but also a data quality assessment method, as the assessment of the quality of all satellite input data (listed in Tables 1 and 2) is a key aspect of EMMA. The second method is the quality as- sessment/quality control (QA/QC) method (Buchwitz et al., 2017b), which is applied to all satellite $\mathrm{XCO}_{2}$ and $\mathrm{XCH}_{4}$ data products generated for the Copernicus Climate Change Service (C3S), i.e., to the merged products but also to all the individual sensor CCI/C3S L2 input products, which are also available via the Copernicus Climate Data Store (CDS) (see products with $\mathrm{CCI} / \mathrm{C} 3 \mathrm{~S}$ product ID listed in Tables 1 and 2).

Key differences between the QA/QC method and the EMMA method are listed as follows. 

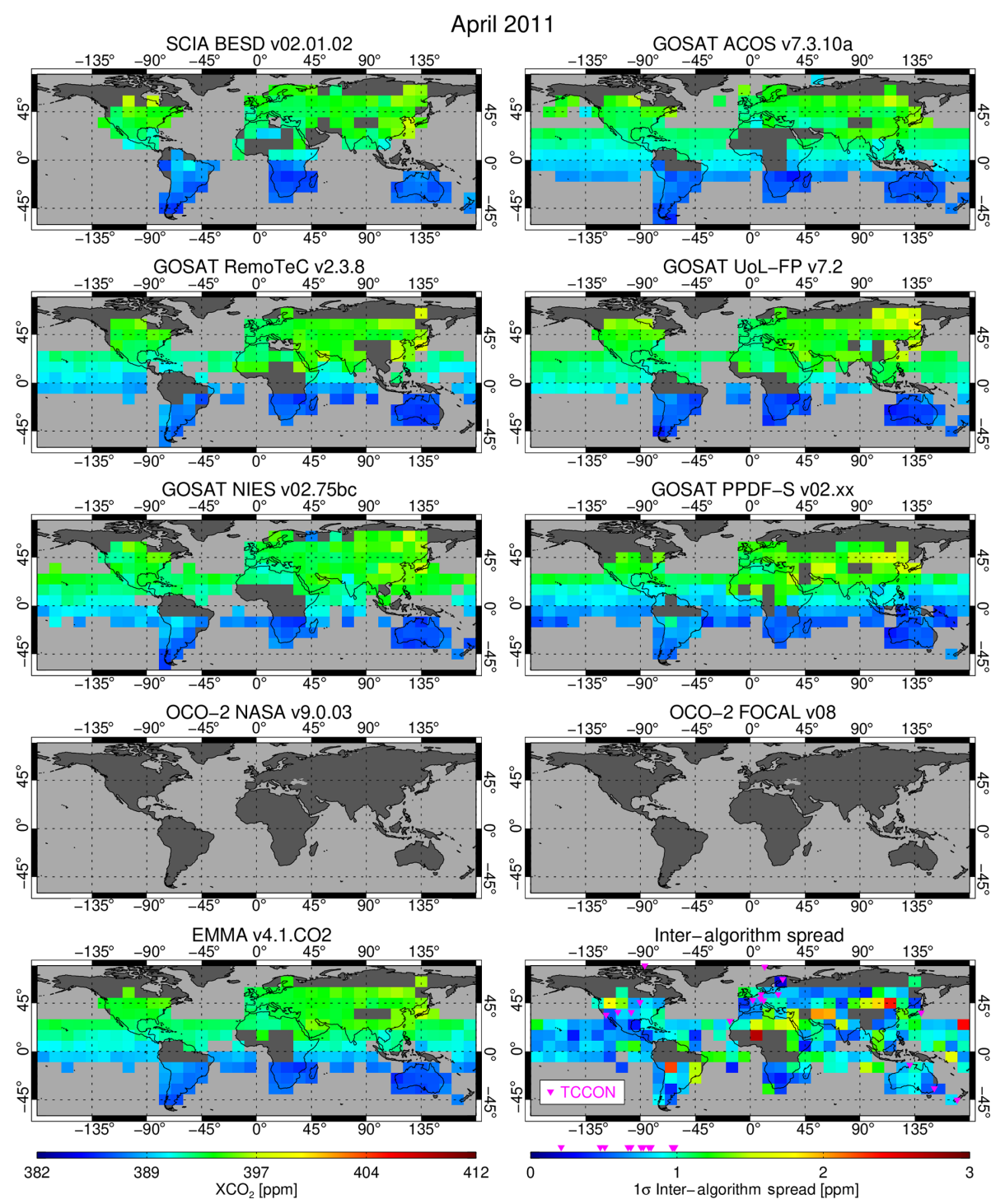

Figure 9. April $2011 \mathrm{XCO}_{2}$ at $10^{\circ} \times 10^{\circ}$ spatial resolution showing (i) the individual sensor/algorithm input data sets (panels in rows 1-4; see Table 1 for details), (ii) EMMA $\mathrm{XCO}_{2}$ (bottom left), and (iii) the inter-algorithm spread (IAS, $1 \sigma$ ) as computed by EMMA (bottom right; see main text for details). Also shown in the bottom-right panel are the locations of the TCCON sites (pink triangles) and the range of IAS values covered by them (see color bar). Note that the OCO-2 maps (row 4) are empty because this satellite was launched after April 2011 (see Fig. 10 for $\mathrm{OCO}-2 \mathrm{XCO}_{2}$ ).

- Colocation criteria: QA/QC used $\pm 2^{\circ}$ latitude and $\pm 4^{\circ}$ longitude as the spatial colocation criterion, but EMMA used $500 \mathrm{~km}$ (both methods use the same temporal colocation criterion of $2 \mathrm{~h}$ ).

- Filtering criterion surface elevation: EMMA requires a surface elevation difference of less than $250 \mathrm{~m}$ between a TCCON site and satellite footprints, whereas the $\mathrm{QA} / \mathrm{QC}$ does not use this filtering criterion.

- A priori correction: both methods correct for the use of different a priori $\mathrm{CO}_{2}$ vertical profiles in the various retrieval algorithms, but $\mathrm{QA} / \mathrm{QC}$ uses the TCCON a priori as common a priori, whereas EMMA uses the SECM2018 model for $\mathrm{CO}_{2}$ and the SC4C2018 model for $\mathrm{CH}_{4}$ (see Sect. 3.1).

- Approach to quantify seasonal bias and linear bias trend: the EMMA method is based on fitting a trend model, which includes an offset term, a slope term, and a sine term for seasonal fluctuations (see Reuter et al., 2019c) and computes the seasonal bias from the standard deviation of the fitted seasonal fluctuation term and obtains the bias trend and its uncertainty from the fitted slope term. The QA/QC method (Buchwitz et al., 2019a) uses (only) a linear fit to obtain the bias trend 

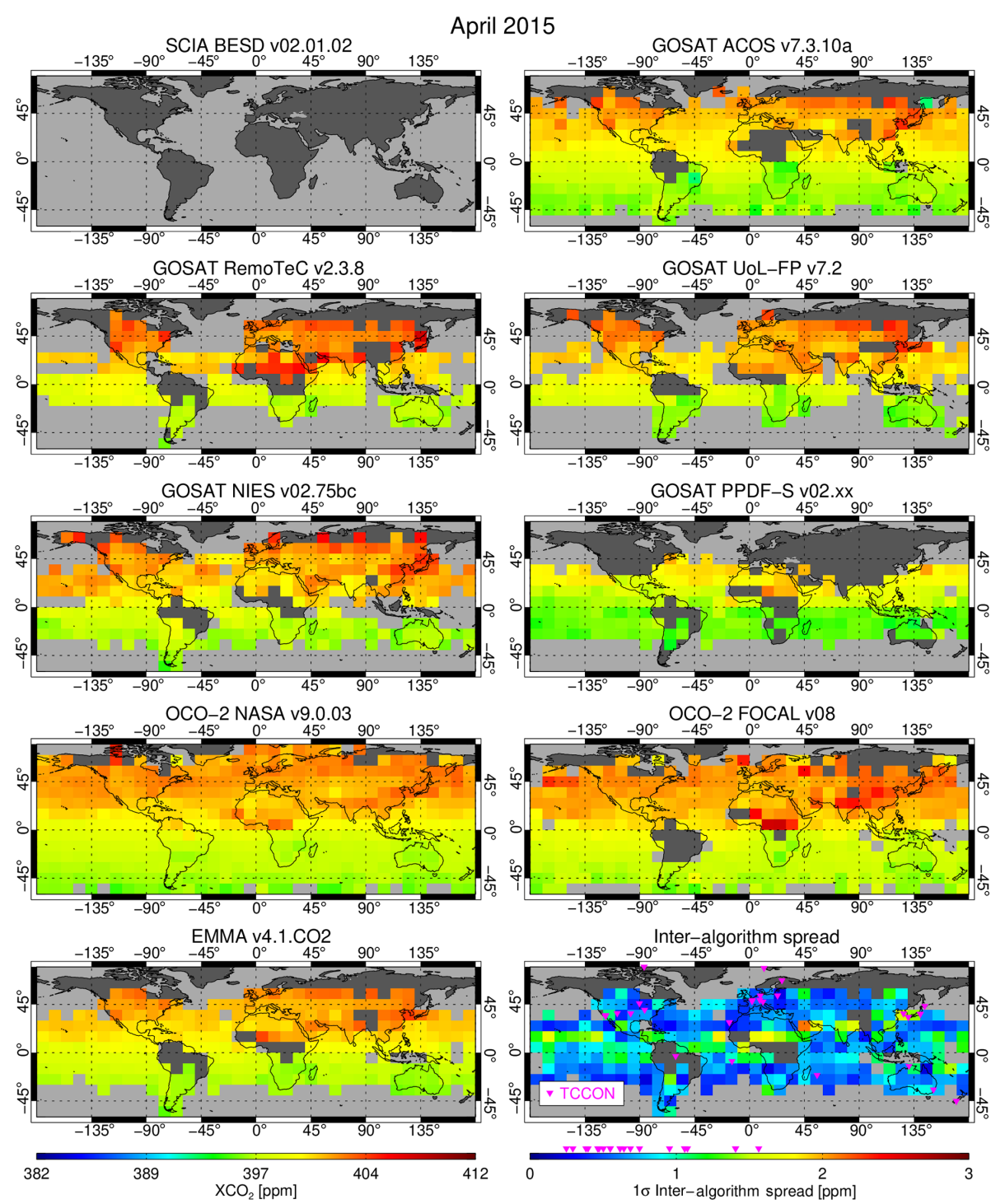

Figure 10. As Fig. 9 but for April 2015. Note that the SCIAMACHY/BESD map (top left) is empty because this product ended in April 2012 (see Fig. 9 for SCIAMACHY/BESD $\mathrm{XCO}_{2}$ ).

and its uncertainty and computes the seasonal bias from the standard deviation of the seasonal biases (as also done by Dils et al., 2014, for their quantity seasonality).

- Criteria for enough data: both algorithms use several different thresholds for the required minimum number of colocations per TCCON site and minimum length of overlapping TCCON time series.

Despite all these differences, quite similar overall figures of merit have been obtained with both methods (see results section, Sect. 4). This indicates that the overall data quality results do not critically depend on the details of the assessment method (the same conclusion has also been reported for earlier comparisons of results from different assessment methods, e.g., Buchwitz et al., 2015, 2017b).

\section{Results and discussion}

\subsection{Products XCO2_EMMA and XCO2_OBS4MIPS (v4.1)}

When generating an EMMA product, a set of standard figures are generated such as Figs. 5 and 6 already discussed but also maps of the EMMA product and of the various input data products for all months of the 2003-2018 time period. Two of these figures are shown here, namely the figures for April 2011 (Fig. 9) and April 2015 (Fig. 10) (note that 2011 is the last full year with data from SCIAMACHY and that 2015 is the first full year with OCO-2 data). The maps in the first four rows of Figs. 9 and 10 show the individual sensor/algorithm L2 input data. As can be seen, the spatial $\mathrm{XCO}_{2}$ patterns are quite similar (e.g., north-south gradient), 
Table 4. Overview validation results at TCCON sites for data product XCO2_EMMA (version 4.1).

\begin{tabular}{|c|c|c|c|c|c|c|c|c|}
\hline \multirow[t]{2}{*}{$\begin{array}{l}\text { TCCON } \\
\text { site }\end{array}$} & \multicolumn{2}{|c|}{$\begin{array}{l}\text { Random error } \\
\text { single obs. } \\
(1 \sigma)(\mathrm{ppm})\end{array}$} & \multicolumn{2}{|c|}{$\begin{array}{l}\text { Uncertainty ratio } \\
\qquad(-)\end{array}$} & \multicolumn{2}{|c|}{$\begin{array}{c}\text { Overall bias } \\
\text { bias satellite - } \\
\text { TCCON (ppm) }\end{array}$} & \multicolumn{2}{|c|}{$\begin{array}{c}\text { Seasonal bias } \\
\text { bias satellite - } \\
\text { TCCON (ppm) }\end{array}$} \\
\hline & QA/QC & EMMA & QA/QC & EMMA & QA/QC & EMMA & QA/QC & EMMA \\
\hline SOD & 1.19 & 1.33 & 1.16 & 1.10 & 0.57 & 0.18 & - & 0.22 \\
\hline BIA & 1.11 & 1.16 & 1.44 & 1.37 & 0.06 & 0.10 & - & 0.26 \\
\hline BRE & 1.66 & 1.30 & 0.90 & 1.14 & 1.09 & 0.55 & - & 0.15 \\
\hline KAR & 1.45 & 1.40 & 0.96 & 0.99 & 1.18 & 0.52 & 1.17 & 0.40 \\
\hline PAR & 1.30 & - & 0.99 & - & -0.49 & - & - & - \\
\hline ORL & 1.18 & 1.40 & 1.15 & 1.04 & 0.30 & 0.45 & 0.75 & 0.39 \\
\hline GAR & 1.48 & 1.46 & 0.91 & 1.04 & 1.28 & 0.36 & 0.83 & 0.22 \\
\hline PFA & 1.08 & 1.27 & 1.31 & 1.11 & 0.09 & -0.37 & 0.70 & 0.18 \\
\hline LAM & 1.26 & 1.47 & 1.08 & 0.95 & -0.09 & -0.61 & 0.17 & 0.38 \\
\hline TSU & 1.54 & - & 0.95 & - & 0.54 & - & 0.61 & - \\
\hline EDW & 1.48 & - & 0.78 & - & 1.16 & - & 0.21 & - \\
\hline CAL & 1.57 & - & 0.75 & - & -0.46 & - & 0.15 & - \\
\hline SAG & 1.41 & - & 1.06 & - & -0.17 & - & 0.31 & - \\
\hline ASC & 1.16 & - & 1.44 & - & 0.65 & - & 0.60 & - \\
\hline DAR & 1.06 & 1.06 & 1.01 & 1.02 & -0.23 & 0.52 & 0.66 & 0.34 \\
\hline REU & 0.75 & - & 1.73 & - & 0.29 & - & - & - \\
\hline WOL & 1.21 & 1.19 & 1.00 & 1.00 & -0.53 & -0.66 & 0.24 & 0.17 \\
\hline LAU & 1.13 & - & 1.03 & - & 0.14 & - & 0.10 & - \\
\hline Mean & 1.28 & 1.30 & 1.15 & 1.07 & 0.30 & 0.10 & 0.50 & 0.27 \\
\hline SD & 0.23 & 0.14 & 0.23 & 0.12 & 0.60 & 0.48 & 0.33 & 0.10 \\
\hline
\end{tabular}

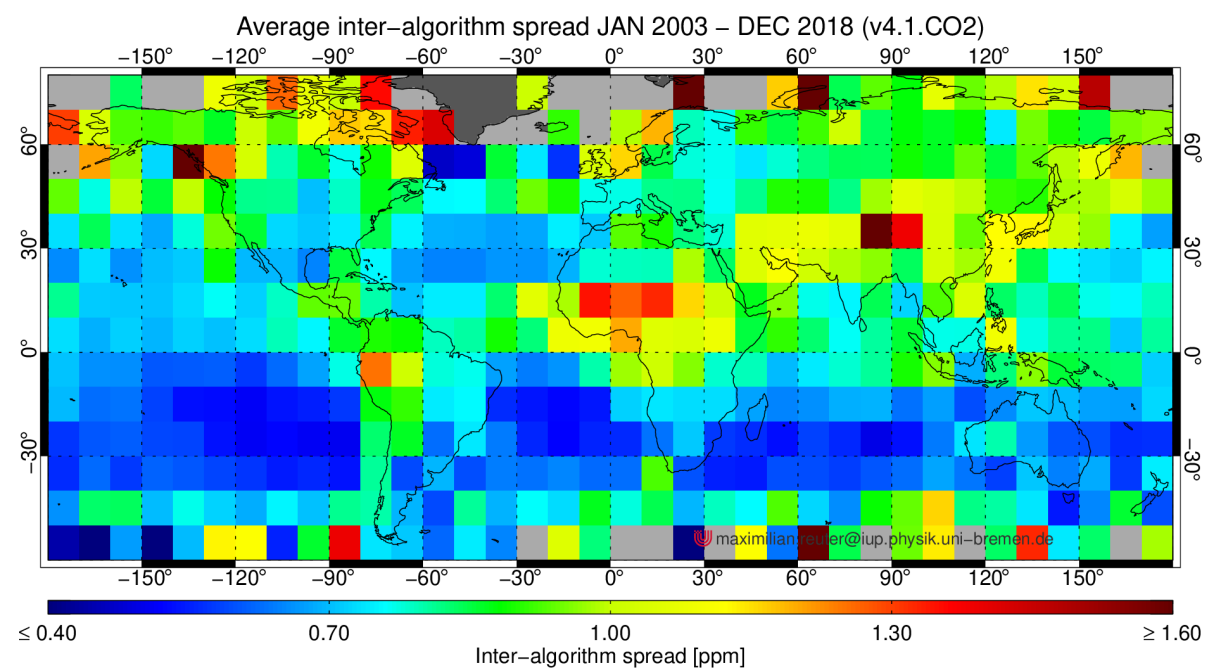

Figure 11. Average $\mathrm{XCO}_{2}$ inter-algorithm spread $(1 \sigma)$ during 2003-2018. As can be seen, the scatter is typically around 1 ppm except over parts of the tropics (in particular central Africa), the Himalayas, and at high latitudes, where the scatter can be larger.

but there are also significant differences, especially with respect to the spatial coverage. The spatial coverage depends on time and is related to the different satellite instruments but also due to algorithm-dependent quality filtering. The largest differences are between the SCIAMACHY BESD product (top left in Fig. 9) compared to the other products, as the SCIAMACHY product is limited to observations over land, whereas the GOSAT and OCO-2 products also have some ocean coverage due to the ocean-glint mode, which permits the acquisition of an adequate signal (and therefore also signal-to-noise ratio) also over the ocean (note that the reflectivity of water is poor outside of sunglint conditions in 
the used SWIR spectral regions around 1.6 and $2 \mu \mathrm{m}$ ). The EMMA product is shown in the bottom-left panels of Figs. 9 and 10, and in the bottom-right panel IAS is shown, which quantifies the level of agreement (or disagreement) among the various satellite input data sets. The IAS maps also show the location of the TCCON sites (pink triangles) and the IAS values at the TCCON sites (see pink triangles above the color bar). As can be seen, the TCCON sites are typically located outside of regions where the IAS is highest.

The average IAS for the entire time period 2003-2018 is shown in Fig. 11. As can be seen, the scatter is typically in the range $0.6-1.1 \mathrm{ppm}$ with the exception of parts of the tropics, in particular central Africa, the Himalayas, parts of southeast Asia, and high latitudes. High latitudes typically correspond to large solar zenith angles, which is a challenge for accurate satellite $\mathrm{XCO}_{2}$ retrievals, as this typically corresponds to low signal and therefore low signal-to-noise ratio resulting in enhanced scatter of the retrieved $\mathrm{XCO}_{2}$. In areas with frequent cloud coverage, such as parts of the tropics, sampling is sparse and this may also contribute to a larger scatter.

Detailed validation results for all individual sensors and the EMMA $\mathrm{XCO}_{2}$ Level 2 data products are shown in Appendix A (Fig. A1) for all TCCON sites. The validation results are summarized in Table 4 (per site) and Table 5 (overall) together with the corresponding results of the QA/QC assessment method.

Table 4 lists all TCCON sites, which fulfill either the EMMA method or the QA/QC method criteria with respect to a minimum number of colocations and length of time series. Listed are the numerical values (in ppm), which have been computed for several figures of merit. This includes (i) the overall estimation of the single-observation random error computed as the standard deviation of the satellite minus TCCON differences; (ii) the uncertainty ratio, which is the ratio of the mean value of the reported $(1 \sigma)$ uncertainty to the standard deviation of the satellite-TCCON difference (computed to validate the reported uncertainties); (iii) the overall bias computed as the mean value of the satellite-TCCON differences; and (iv) the seasonal bias, computed as the standard deviation of the biases determined for the four seasons. Also shown in the last two rows are the mean value and the standard deviation of the values listed per TCCON site in the rows above. Several of these values have been used to compute the values listed in Table 5, which shows the overall summary of the quality assessment.

Table 5 lists (i) the mean value of the single-observation random error, (ii) the global bias computed as the mean value of the biases at the various TCCON sites, (iii) the regional bias computed as the standard deviation of the biases at the various TCCON sites, (iv) the mean seasonal bias, and (v) the spatiotemporal bias computed as the root sum square of the regional and of the seasonal bias. The spatiotemporal bias is used to quantify the achieved performance for relative accuracy, which characterizes the spatially and temporally vary-
Table 5. Validation summary for data product XCO2_EMMA (version 4.1).

\begin{tabular}{|c|c|c|c|}
\hline \multirow[t]{2}{*}{ Parameter } & \multicolumn{2}{|c|}{ Assessment method } & \multirow[t]{2}{*}{ Mean } \\
\hline & $\mathrm{QA} / \mathrm{QC}$ & EMMA & \\
\hline $\begin{array}{l}\text { Random error single } \\
\text { observations }(1 \sigma)(\mathrm{ppm})\end{array}$ & 1.28 & 1.30 & 1.29 \\
\hline Global bias (ppm) & 0.30 & 0.10 & 0.20 \\
\hline Regional bias $(1 \sigma)(\mathrm{ppm})$ & 0.60 & 0.48 & 0.54 \\
\hline Seasonal bias $(1 \sigma)(\mathrm{ppm})$ & 0.50 & 0.27 & 0.39 \\
\hline $\begin{array}{l}\text { Spatiotemporal bias }(1 \sigma) \\
(\mathrm{ppm})\end{array}$ & 0.78 & 0.55 & 0.66 \\
\hline
\end{tabular}

ing component of the bias (i.e., neglects a possible global bias (global offset), which is reported separately).

The linear bias trend has also been computed by fitting a line to the satellite-TCCON differences (not shown here). The mean value of the linear trend (slope) and its uncertainty $(1 \sigma$, obtained from the standard deviation of the slope at the various TCCON sites) are $-0.05 \pm 0.06 \mathrm{ppm} \mathrm{yr}^{-1}$ for the EMMA method and $-0.06 \pm 0.09 \mathrm{ppm} \mathrm{yr}^{-1}$ for the QA/QC method. This means that no significant long-term bias trend has been detected; i.e., the satellite product is stable.

As can be seen from Table 5, the values computed independently using the EMMA and the QA/QC assessment methods are quite similar, which gives not only confidence in the overall quality assessment summary documented in Table 5 but also in the products and the used validation methods.

Note however that the quality of the satellite data (at least at TCCON sites) is very likely better than Table 5 suggests (i) because the TCCON retrievals are not free of errors (the $1 \sigma \mathrm{XCO}_{2}$ uncertainty is about $0.4 \mathrm{ppm}$; Wunch et al., 2010) and (ii) because of the representation error originating from the (real) spatiotemporal variability of $\mathrm{XCO}_{2}$ around the TCCON sites. The overall error related to this is difficult to quantify, but some indication can potentially be obtained by additional assessment results such as the one shown in Fig. 12. Figure 12 shows the biases as obtained with the EMMA method at the various TCCON sites used for the EMMA method comparisons. Shown are not only the mean satellite-TCCON differences as obtained for the EMMA product but also for all the individual sensor/algorithm input products. The differences are shown as anomalies with respect to the mean; i.e., the sum of the differences in each row is zero. This is equivalent to assuming that for a given satellite product the mean value over all TCCON sites is zero. As can be seen from Fig. 12, the satellite-TCCON differences are dominantly positive (orange and red colors) for higherlatitude TCCON sites and mostly negative (blue colors) for lower-latitude TCCON sites. In order to rule out that this is an artifact of the EMMA assessment method, the overall biases computed with the QA/QC method and biases computed 
Table 6. TCCON $\mathrm{XCO}_{2}$ bias in parts per million (ppm; satellite - TCCON). "-" means that the number of available colocations is less than the threshold required by the corresponding assessment method. Note that this table includes only a subset of the 10 sites shown in Fig. 12 , namely only those sites with a mean bias being considerably (more than 1.5 times) larger than the standard deviation of the biases.

\begin{tabular}{llrrrr}
\hline \multirow{2}{*}{ Satellite product } & \multirow{2}{*}{ Assessment method } & \multicolumn{4}{c}{ TCCON site } \\
\cline { 3 - 6 } & & SOD & KAR & ORL & LAM \\
\hline XCO2_EMMA & QA/QC & 0.57 & 1.18 & 0.30 & -0.09 \\
& EMMA & 0.18 & 0.52 & 0.45 & -0.61 \\
\hline CO2_SCI_BESD & QA/QC & 0.27 & - & 0.09 & -0.27 \\
& EMMA & 0.32 & 0.39 & 0.25 & -0.08 \\
\hline CO2_GOS_OCFP & QA/QC & 0.32 & 0.83 & 0.33 & -0.32 \\
& EMMA & 0.25 & 0.40 & 0.23 & -0.61 \\
& DP & 0.57 & 0.11 & 0.05 & -0.33 \\
\hline CO2_GOS_SRFP & QA/QC & 0.49 & 1.09 & 0.31 & -0.59 \\
& EMMA & 0.61 & 0.49 & 0.20 & -0.96 \\
GOS NIES & DP & 0.89 & 0.49 & 0.49 & -0.41 \\
GOS NASA & EMMA & 0.29 & 0.50 & 0.22 & -0.78 \\
OCO-2 FOCAL & EMMA & 1.04 & 0.14 & 0.03 & -0.73 \\
OCO-2 NASA & EMMA & 0.02 & 0.18 & 0.29 & -0.34 \\
\hline Mean & & 0.40 & 0.29 & 0.36 & -0.41 \\
\hline Standard deviation & & 0.44 & 0.51 & 0.26 & -0.47 \\
\hline Assessment method DP is the method used by the data provider. For a & see Boesch et al. (2019). For \\
b see Wu et al. (2019). & & \multicolumn{4}{c}{}
\end{tabular}

by the individual product data providers (DPs) have also been derived. These biases have been used to compute - for each of the 10 TCCON sites shown in Fig. 12 - the mean bias and the standard deviation of these biases. For 4 of these 10 sites the mean bias is considerably (more than 1.5 times) larger than the standard deviation of the biases, and the corresponding results for these four sites are shown in Table 6. This does not necessarily mean that these sites have the largest biases. This only means that the derived biases at these sites are (independent of their magnitude) the most consistent across all satellite products used for comparison. As can be seen from Table 6, the biases are always positive at Sodankylä, Karlsruhe, and Orléans and always negative at Lamont. Note that this does not imply that all derived biases are significant as some biases are very small, e.g., the FOCAL bias at Sodankylä, which is only $0.02 \mathrm{ppm}$. Because it is unlikely that all three satellites and several retrieval algorithms produce $\mathrm{XCO}_{2}$ products with similar biases at a given TCCON site, this provides an indication of biases either due to representation errors or due to biases within the TCCON data (Table 6). Note that these biases are within the accuracy stated by TCCON, which is $0.8 \mathrm{ppm}(2 \sigma)$ (Wunch et al., 2010, Hedelius et al., 2017). The accuracy of the TCCON data will be improved for the next data release (planned for 2020). This new TCCON data set will allow for better identification of the causes for the observed biases.
The XCO2_OBS4MIPS product has also been directly compared with TCCON using a comparison method based on the comparison of the monthly satellite product with TCCON monthly mean values. The results are shown in Fig. 13. As can be seen, the mean difference (satellite - TCCON) is $0.18 \mathrm{ppm}$ (which is close to the mean value of the global bias of $0.20 \mathrm{ppm}$ listed in Table 5), the standard deviation is $1.18 \mathrm{ppm}$ (as expected, because of the spatiotemporal averaging, which is somewhat smaller than the value of $1.29 \mathrm{ppm}$ obtained for the XCO2_EMMA product listed in Table 5), and the linear correlation coefficient is 0.99 . The spatiotemporal bias, computed as the standard deviation of 3-monthly averages at the TCCON sites listed in Fig. 13, is 0.7 ppm.

Figure 1 presents an overview of the $\mathrm{XCO}_{2}$ data product in terms of time series for three latitude bands and global maps. $\mathrm{XCO}_{2}$ is increasing almost linearly during the 16-year time period (for a discussion of the derived annual growth rates see Sect. 4.3). The main reason for this increase is $\mathrm{CO}_{2}$ emission due to burning of fossil fuels (Le Quéré et al., 2018). The seasonal cycle, which is caused primarily by quasi-regular uptake and release of atmospheric $\mathrm{CO}_{2}$ by the terrestrial vegetation due to photosynthesis and respiration (e.g., Kaminski et al., 2017, Yin et al., 2018), is most pronounced over the Northern Hemisphere. The half-yearly maps for 2003 are based on SCIAMACHY on board ENVISAT (Burrows et al., 1995; Bovensmann et al., 1999) satellite data, and the maps for 2018 contain data from the GOSAT (since 2009) (Kuze et 
Table 7. Overview validation results at TCCON sites for data product XCH4_EMMA (version 4.1).

\begin{tabular}{|c|c|c|c|c|c|c|c|c|}
\hline \multirow[t]{2}{*}{$\begin{array}{l}\text { TCCON } \\
\text { site }\end{array}$} & \multicolumn{2}{|c|}{$\begin{array}{l}\text { Random error } \\
\text { single obs. } \\
\text { (ppb) }\end{array}$} & \multicolumn{2}{|c|}{$\begin{array}{l}\text { Uncertainty ratio } \\
\qquad(-)\end{array}$} & \multicolumn{2}{|c|}{$\begin{array}{c}\text { Overall bias } \\
\text { satellite - } \\
\text { TCCON (ppb) }\end{array}$} & \multicolumn{2}{|c|}{$\begin{array}{l}\text { Seasonal bias } \\
\text { satellite - } \\
\text { TCCON (ppb) }\end{array}$} \\
\hline & QA/QC & EMMA & QA/QC & EMMA & QA/QC & EMMA & QA/QC & EMMA \\
\hline SOD & 14.2 & 14.9 & 1.11 & 1.05 & 2.2 & 4.5 & - & 1.6 \\
\hline ETL & 15.2 & - & 0.98 & - & 3.0 & - & - & - \\
\hline BIA & 17.6 & 13.6 & 0.91 & 0.99 & -2.3 & 0.7 & 4.1 & 1.5 \\
\hline BRE & 12.3 & 13.9 & 1.13 & 1.01 & -2.1 & -0.5 & - & 2.8 \\
\hline KAR & 12.8 & 14.1 & 1.10 & 0.97 & -5.3 & 1.4 & 1.3 & 1.7 \\
\hline PAR & 11.3 & - & 1.13 & - & -7.9 & - & 1.1 & - \\
\hline ORL & 11.3 & 12.8 & 1.17 & 1.05 & -3.0 & 0.8 & 1.0 & 1.5 \\
\hline GAR & 39.0 & 14.2 & 0.74 & 1.04 & 0.2 & 1.7 & 1.8 & 3.3 \\
\hline PFA & 61.7 & 13.9 & 0.92 & 1.01 & -9.1 & 4.4 & 3.7 & 2.9 \\
\hline LAM & 47.1 & 13.1 & 0.89 & 0.91 & -0.6 & -1.0 & 0.6 & 1.8 \\
\hline TSU & 13.2 & - & 1.08 & - & -1.3 & - & 2.7 & - \\
\hline EDW & 15.9 & - & 0.82 & - & 1.8 & - & 3.0 & - \\
\hline CAL & 15.9 & - & 0.82 & - & -10.8 & - & 2.7 & - \\
\hline SAG & 12.5 & - & 1.06 & - & -2.7 & - & 1.9 & - \\
\hline ASC & 10.1 & - & 1.07 & - & -5.3 & - & 1.2 & - \\
\hline DAR & 58.1 & 10.0 & 1.21 & 1.02 & -18.2 & -5.7 & 3.1 & 1.9 \\
\hline REU & 9.8 & - & 0.99 & - & -3.0 & - & - & - \\
\hline WOL & 16.5 & 15.6 & 0.76 & 0.74 & -8.8 & -6.4 & 2.6 & 5.7 \\
\hline LAU & 9.0 & - & 1.12 & - & -3.1 & - & 1.7 & - \\
\hline Mean & 21.2 & 13.6 & 1.01 & 0.98 & -4.0 & 0.0 & 2.2 & 2.5 \\
\hline SD & 16.8 & 1.5 & 0.16 & 0.09 & 5.2 & 3.7 & 1.1 & 1.3 \\
\hline
\end{tabular}

al., 2016) and OCO-2 (since 2014) (Crisp et al., 2004) satellites. GOSAT and OCO-2 also provide good-quality $\mathrm{XCO}_{2}$ retrievals over the oceans due to their sunglint observation mode.

\subsection{Products XCH4_EMMA and XCH4_OBS4MIPS (v4.1)}

As for $\mathrm{XCO}_{2}$, monthly maps have also been generated for the EMMA $\mathrm{XCH}_{4}$ data product. Two examples are shown in Fig. 14 for September 2010 and in Fig. 15 for September 2018. The individual sensor $\mathrm{XCH}_{4}$ input data are shown in the first four rows, and the EMMA $\mathrm{XCH}_{4}$ product is shown in the bottom-left panel. The bottom-right panel shows the IAS. As can be seen, the spatial patterns of the $\mathrm{XCH}_{4}$ maps are similar but not identical. The IAS shows a quite large variability. The scatter is larger compared to the corresponding $\mathrm{XCO}_{2}$ IAS (Figs. 9 and 10, bottom-right panels), and spatially the grid cells with larger spread are more equally distributed over the globe but with largest differences over the southern part of Asia.

Detailed validation results are shown in Appendix A (Fig. A2), and the validation results are summarized in Tables 7 and 8, which have the same structure as the corresponding $\mathrm{XCO}_{2}$ tables (Tables 4 and 5). These tables also list the results of the QA/QC assessment method, which results in quite similar (within a few ppb) overall quality assessment results (Table 8) as obtained with the EMMA method. The linear bias trend has also been computed by fitting a line to the satellite-TCCON differences (not shown here). The mean value of the linear trend (slope) and its uncertainty ( $1 \sigma$, obtained from the standard deviation of the slope at the various TCCON sites) are $-0.1 \pm 0.4 \mathrm{ppb} \mathrm{yr}^{-1}$ for the EMMA method and $0.5 \pm 0.8 \mathrm{ppb} \mathrm{yr}^{-1}$ for the QA/QC method. As for $\mathrm{XCO}_{2}$, this means that no significant long-term bias trend has been detected; i.e., the satellite product is stable.

Figure 16 shows the TCCON station $\mathrm{XCH}_{4}$ bias anomaly as also shown for $\mathrm{XCO}_{2}$ in Fig. 12; i.e., Fig. 16 shows the biases as obtained with the EMMA method at the various TCCON sites used for the EMMA method comparisons. As for $\mathrm{XCO}_{2}$ not only the mean satellite-TCCON differences as obtained for the EMMA product are shown but also the differences for all the individual sensor/algorithm input products. The differences are shown as anomalies with respect to the mean; i.e., the sum of the differences in each row is zero. As can be seen from Fig. 16, the pattern of satelliteTCCON $\mathrm{XCH}_{4}$ differences has some similarity with the $\mathrm{XCO}_{2}$ difference pattern shown in Fig. 12. For example, the differences are mostly positive at Sodankylä and GarmischPartenkirchen and mostly negative at Darwin and Wollongong. But there are also significant differences, for example, 


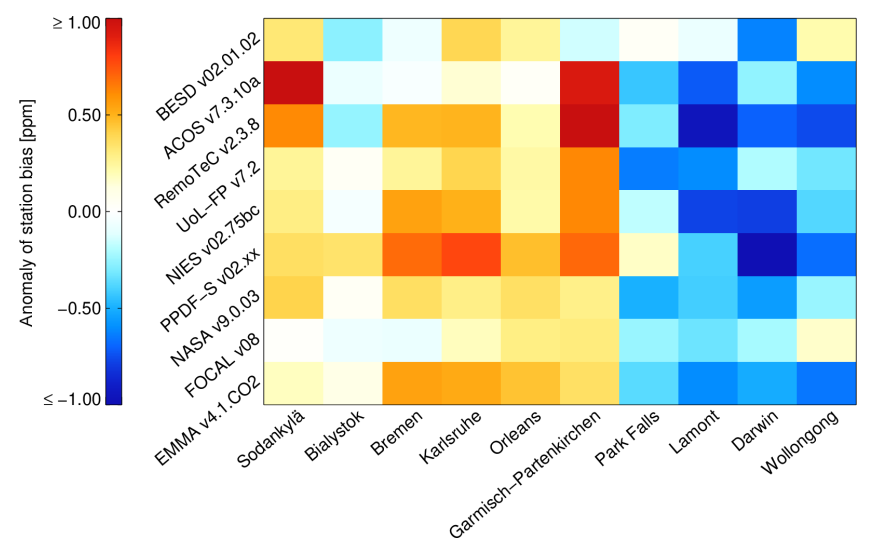

Figure 12. Average $\mathrm{XCO}_{2}$ differences (satellite - TCCON) for the different satellite $\mathrm{XCO}_{2}$ products at $10 \mathrm{TCCON}$ sites as used by the EMMA assessment method. The differences are shown as anomalies; i.e., the sum of the values corresponding to a given row is zero. Note that here "ACOS" refers to NASA's ACOS algorithm as applied to GOSAT and that "NASA" refers to NASA's ACOS algorithm as applied to OCO-2.

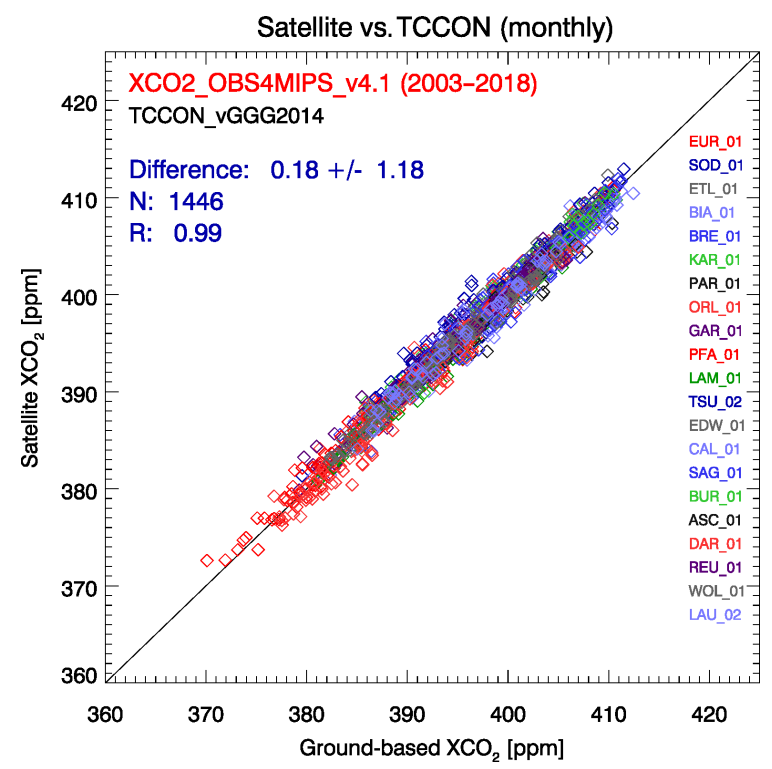

Figure 13. Summary of the comparison of product XCO2_OBS4MIPS with TCCON monthly mean $\mathrm{XCO}_{2}$ (each symbol corresponds to one month and to one TCCON site; each color corresponds to a different TCCON site; TCCON site colors and site IDs (see Table 3) are shown on the right). The comparison is based on 1446 monthly values. The mean difference (satellite TCCON) is $0.18 \mathrm{ppm}$ and the standard deviation of the difference is $1.18 \mathrm{ppm}$. The linear correlation coefficient $R$ is 0.99 .

with respect to the sign of the bias (e.g., Park Falls, Bremen, Karlsruhe).

The XCH4_OBS4MIPS product has also been directly compared with TCCON (Fig. 17) using the same method as also used for product XCO2_OBS4MIPS (Fig. 13). As
Table 8. Validation summary for data product XCH4_EMMA (version 4.1).

\begin{tabular}{lrrr}
\hline Parameter & \multicolumn{2}{c}{ Assessment method } & \multirow{2}{*}{ Mean } \\
\cline { 2 - 3 } & QA/QC & EMMA & \\
\hline Random error single & 21.2 & 13.6 & 17.4 \\
observations $(1 \sigma)(\mathrm{ppb})$ & & & \\
Global bias $(\mathrm{ppb})$ & -4.0 & 0.0 & -2.0 \\
Regional bias $(1 \sigma)(\mathrm{ppb})$ & 5.2 & 3.7 & 4.4 \\
Seasonal bias $(1 \sigma)(\mathrm{ppb})$ & 2.2 & 2.5 & 2.3 \\
Spatiotemporal bias $(1 \sigma)$ & 5.6 & 4.4 & 5.0 \\
$(\mathrm{ppb})$ & & & \\
\hline
\end{tabular}

can be seen from Fig. 17, the mean difference (satellite TCCON) is $-2.88 \mathrm{ppb}$ (which is close to the mean value of the global bias of $-2.0 \mathrm{ppb}$ of product XCH4_EMMA listed in Table 8), the standard deviation is $8.65 \mathrm{ppb}$ (as expected, because of the averaging, which is somewhat smaller than the value of $17.4 \mathrm{ppb}$ obtained for the XCH4_EMMA product listed in Table 8), and the linear correlation coefficient is 0.97 .

Figure 2 presents an overview of the $\mathrm{XCH}_{4}$ data product in terms of time series for three latitude bands and global maps. As can be seen, $\mathrm{XCH}_{4}$ was nearly constant during 2003-2006 (apart from seasonal fluctuations) but has been increasing since 2007 (for a discussion of the trend and annual growth rates see Sect. 4.3). The reason for this is likely a combination of increasing natural (e.g., wetlands) and anthropogenic (e.g., fossil fuel related) emissions and possibly decreasing sinks (hydroxyl, OH, radical), but it does not seem currently possible to be more definitive (e.g., Worden et al., 2017; Nisbet et al., 2019; Turner et al., 2019; Howarth, 2019; Schaefer, 2019).

\subsection{Annual growth rates}

Finally, we present an update and extension of the year 2003-2016 annual $\mathrm{XCO}_{2}$ growth rates shown in Buchwitz et al. (2018), using the new OBS4MIPS v4.1 $\mathrm{XCO}_{2}$ data set covering the time period 2003-2018 (Fig. 18). Figure 18a shows the time series of the globally averaged OBS4MIPS version $4.1 \mathrm{XCO}_{2}$ data product over land. In contrast to Buchwitz et al. (2018), the analysis presented here is based on data over land only as this permits the generation of a time series with better internal consistency (note that the $\mathrm{XCO}_{2}$ OBS4MIPS product is land only for 2003-2008). The average growth rate during 2010-2018, i.e., for the time period where an ensemble of GOSAT and OCO-2 data has been used, is $2.28 \pm 0.04 \mathrm{ppm} \mathrm{yr}^{-1}$. As can be seen from Fig. 18b, the year 2017 and 2018 growth rates are less than the growth rates of the years 2015 and 2016, which were years with a strong El Niño. The $\mathrm{XCO}_{2}$ growth rates are in reasonable agreement with the global $\mathrm{CO}_{2}$ growth rates published by National Oceanic and Atmospheric Ad- 

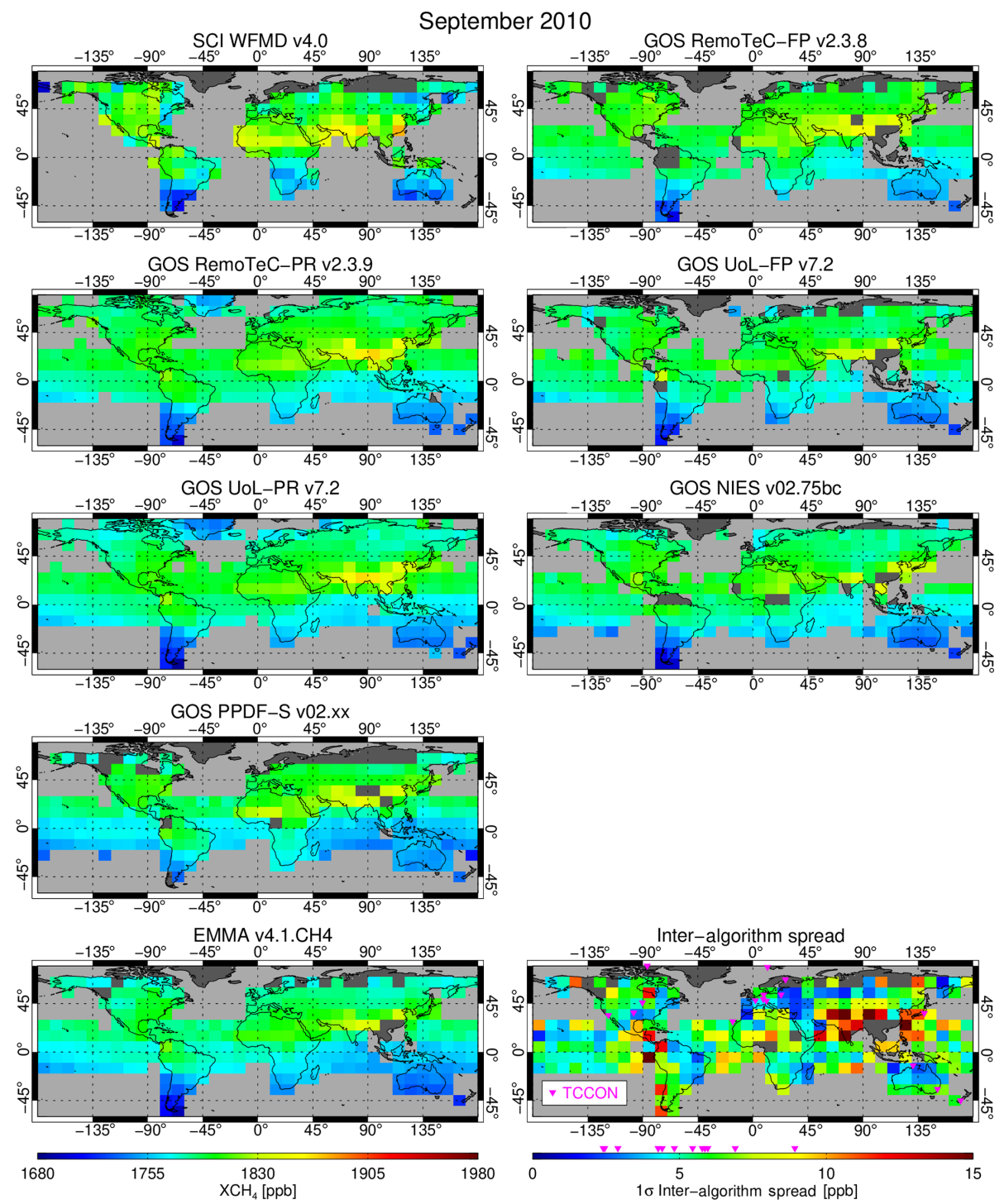

Figure 14. September $2010 \mathrm{XCH}_{4}$ at $10^{\circ} \times 10^{\circ}$ spatial resolution showing (i) the individual sensor/algorithm input data sets (panels in rows 1-4; see Table 2 for details), (ii) EMMA $\mathrm{XCH}_{4}$ (bottom left), and (iii) the inter-algorithm spread (IAS, $1 \sigma$ ) as computed by EMMA (bottom right; see main text for details). Also shown in the bottom-right panel are the locations of the TCCON sites (pink triangles) and the range of IAS values covered by them (see color bar).

ministration (NOAA) (shown in blue color in Fig. 18b), which are based on marine surface $\mathrm{CO}_{2}$ observations (ftp: //aftp.cmdl.noaa.gov/products/trends/co2/co2_gr_gl.txt; last access: 30 July 2019). As can be seen from Fig. 18b, the agreement of the satellite-derived $\mathrm{XCO}_{2}$ growth rates with the NOAA surface- $\mathrm{CO}_{2}$-based growth rates is better from year 2010 onwards compared to the time period before when the EMMA data set consists only of one SCIAMACHY data set instead of the full ensemble. For 2018, the $\mathrm{XCO}_{2}$ growth rate is $2.1 \pm 0.5 \mathrm{ppm} \mathrm{yr}^{-1}$, which is lower than the NOAA surface $\mathrm{CO}_{2}$ growth rate of $2.43 \pm 0.08 \mathrm{ppm} \mathrm{yr}^{-1}$. Note that the $1 \sigma$ uncertainty ranges of the two growth rate estimates overlap, which indicates that the two growth rate estimates are consistent.

The growth rate of atmospheric methane is also an important quantity (e.g., Nisbet et al., 2019). The method of Buchwitz et al. (2018) has now also been used to compute annual $\mathrm{XCH}_{4}$ growth rates from satellite $\mathrm{XCH}_{4}$ retrievals. Figure 19a shows the time series of the globally averaged OBS4MIPS version $4.1 \mathrm{XCH}_{4}$ data product over land. As shown by the linear fit, the average growth rate is $7.9 \pm 0.2 \mathrm{ppbyr}^{-1}$ during $2010-2018$, i.e., for the time period where an ensemble of GOSAT data has been used. The annual growth rates are shown in Fig. 19b for the satellitederived $\mathrm{XCH}_{4}$ (red) and for the NOAA growth rates (ftp: 

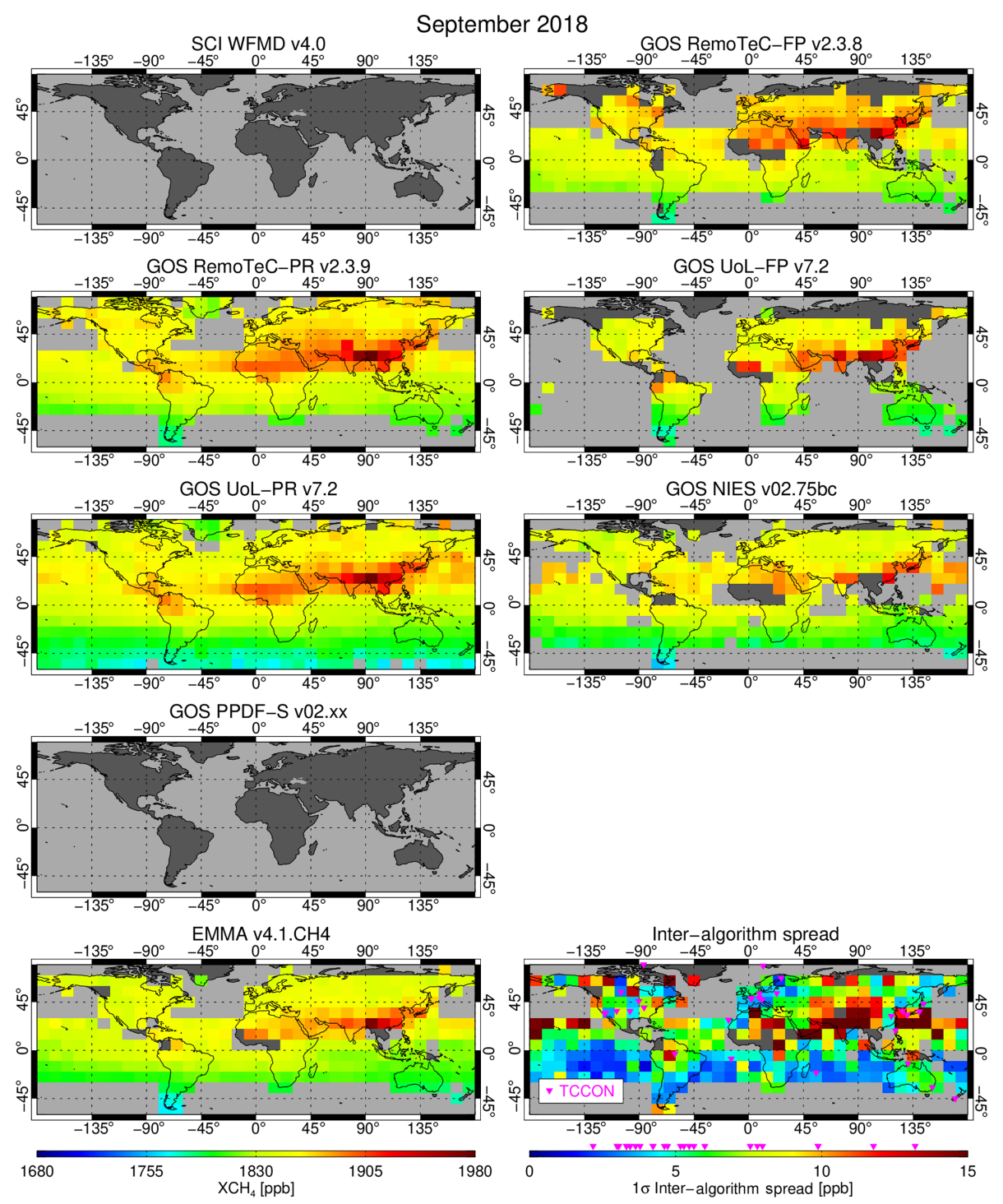

Figure 15. As Fig. 14 but for September 2018. Note that the SCIAMACHY/WFMD map (top left) is empty because this product ended in April 2012 (see Fig. 14 for SCIAMACHY/WFMD XCH 4 ). For product GOSAT/PPDF (row 4) no data were available for this month (see Fig. 14 for GOSAT/PPDF $\mathrm{XCH}_{4}$ ).

//aftp.cmdl.noaa.gov/products/trends/ch4/ch4_gr_gl.txt; last access: 30 July 2019) derived from marine surface $\mathrm{CH}_{4}$ observations. For 2018, the $\mathrm{XCH}_{4}$ growth rate is $10 \pm$ $6 \mathrm{ppb} \mathrm{yr}^{-1}$, which is close to the NOAA surface $\mathrm{CH}_{4}$ growth rate of $9.46 \pm 0.56 \mathrm{ppb} \mathrm{yr}^{-1}$.

\section{Summary and conclusions}

Satellite-derived ensemble $\mathrm{XCO}_{2}$ and $\mathrm{XCH}_{4}$ data products have been generated and validated. These data products are the version 4.1 Level 2 (L2) products XCO2_EMMA and XCH4_EMMA and the Level 3 (L3) products XCO2_OBS4MIPS and XCH4_OBS4MIPS and cover the time period 2003-2018. The data products are freely avail- able for interested users via the Copernicus Climate Data Store (CDS, https://cds.climate.copernicus.eu/, last access: 10 January 2020), where also earlier versions of these data products are accessible. The L2 products have been generated with an adapted version of the EMMA algorithm (Reuter et al., 2013), and the L3 products have been generated by gridding (averaging) the EMMA L2 product to obtain products at monthly time and $5^{\circ} \times 5^{\circ}$ spatial resolution in Obs4MIPS format. The products have been validated by comparisons with TCCON ground-based $\mathrm{XCO}_{2}$ and $\mathrm{XCH}_{4}$ retrievals using TCCON version GGG2014.

From January 2003 to March 2009 the products are based on SCIAMACHY/ENVISAT, and from April 2009 onwards the products use an ensemble of one SCIAMACHY (until 


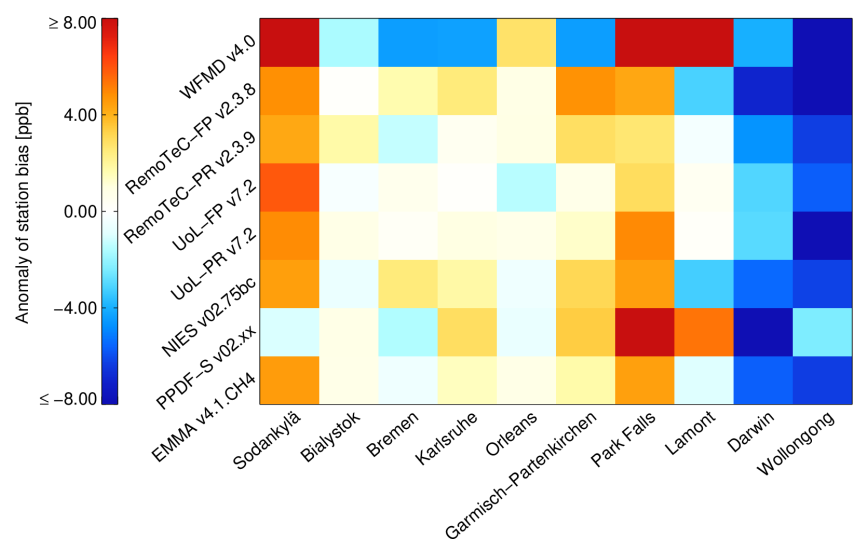

Figure 16. As Fig. 12 but for $\mathrm{XCH}_{4}$, i.e., average $\mathrm{XCH}_{4}$ differences (satellite $-\mathrm{TCCON}$ ) for the different satellite $\mathrm{XCH}_{4}$ products at 10 TCCON sites as used by the EMMA assessment method. The differences are shown as anomalies; i.e., the sum of the values corresponding to a given row is zero.

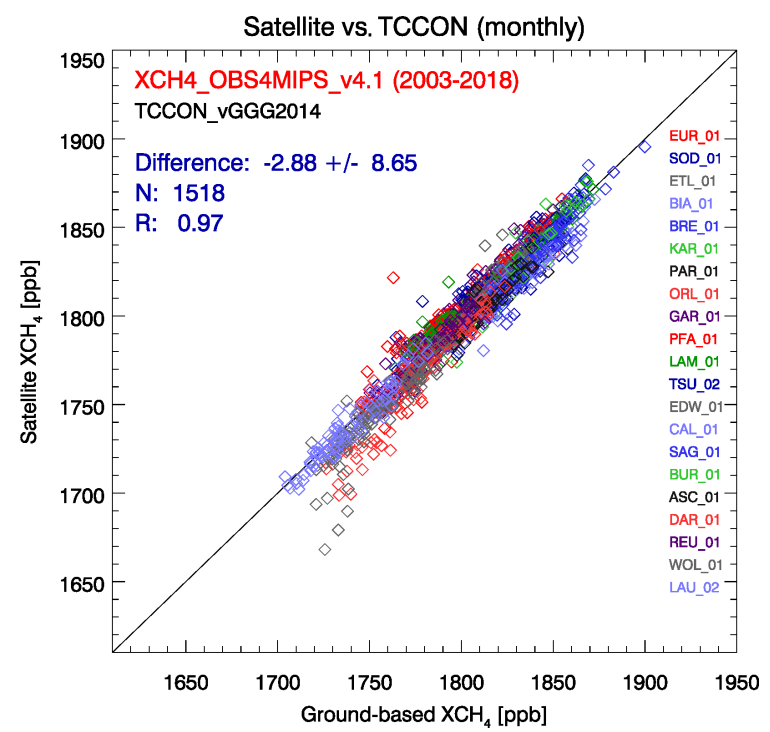

Figure 17. Summary of the comparison of product XCH4_OBS4MIPS with TCCON monthly mean $\mathrm{XCH}_{4}$. The comparison is based on 1518 monthly values. The mean difference (satellite - TCCON) is $-2.88 \mathrm{ppb}$ and the standard deviation of the difference is $8.65 \mathrm{ppb}$. The linear correlation coefficient $R$ is 0.97 .

early 2012) and several GOSAT products. The $\mathrm{XCO}_{2}$ products contain in addition L2 products from NASA's OCO-2 mission from September 2014 onwards.

The EMMA algorithm selects for each month and each $10^{\circ} \times 10^{\circ}$ grid cell one of the available products, i.e., one from the existing ensemble of L2 input products, and transfers all relevant information (including averaging kernel etc.) from the selected L2 input product into the merged EMMA L2 product. The selected product is the median product. The main purpose of EMMA is to generate a Level 2 product, which covers an as-long-as-possible time series (longer than any of the individual sensor input data sets) with as-high-aspossible accuracy including all information needed, e.g., for surface flux inverse modeling. The median approach helps to reduce the occurrence of potential outliers and thus reduces spatial and temporal biases in the generated data products.

Detailed quality assessment results based on comparisons with TCCON ground-based retrievals have been presented. We found that the $\mathrm{XCO}_{2}$ Level 2 data set at the TCCON validation sites can be characterized by the following figures of merit (the corresponding values for the Level 3 product are listed in brackets) - single-observation random error ( $1 \sigma): 1.29 \mathrm{ppm}$ (monthly: $1.18 \mathrm{ppm}$ ); global bias: $0.20 \mathrm{ppm}(0.18 \mathrm{ppm})$; and spatiotemporal bias or relative accuracy $(1 \sigma): 0.66 \mathrm{ppm}(0.70 \mathrm{ppm})$. The corresponding values for the $\mathrm{XCH}_{4}$ products are single-observation random error $(1 \sigma)$ ): $17.4 \mathrm{ppb}$ (monthly: $8.7 \mathrm{ppb}$ ); global bias: $-2.0 \mathrm{ppb}$ $(-2.9 \mathrm{ppb})$, spatiotemporal bias $(1 \sigma): 5.0 \mathrm{ppb}(4.9 \mathrm{ppb})$. It has also been found that the data products exhibit very good long-term stability as no significant linear bias trends have been identified.

The new data sets have also been used to derive annual $\mathrm{XCO}_{2}$ and $\mathrm{XCH}_{4}$ growth rates, which are in reasonable to good agreement with growth rates from the National Oceanic and Atmospheric Administration (NOAA) based on marine surface observations.

An important application for the EMMA products is to use them together with inverse modeling to obtain improved information on regional-scale $\mathrm{CO}_{2}$ (e.g., Houweling et al., 2015) and $\mathrm{CH}_{4}$ (e.g., Alexe et al., 2015) surface fluxes. Applications for the corresponding OBS4MIPS products are, for example, climate model comparisons (e.g., Lauer et al., 2017) and studies related to annual growth rates (e.g., Buchwitz et al., 2018). It is however important to note that these merged products are not necessarily the most optimal products for all applications as they do not contain all data from a given satellite sensor. For example, users interested primarily in emissions from power plants or other localized $\mathrm{CO}_{2}$ sources will prefer the original OCO-2 Level 2 data product (e.g., Nassar et al., 2017; Reuter et al., 2019a). Especially for users interested in only parts of the time series it is recommended to use the individual sensor products in addition to the merged product as this may significantly increase the robustness, reliability, and uncertainty characterization of key findings. 


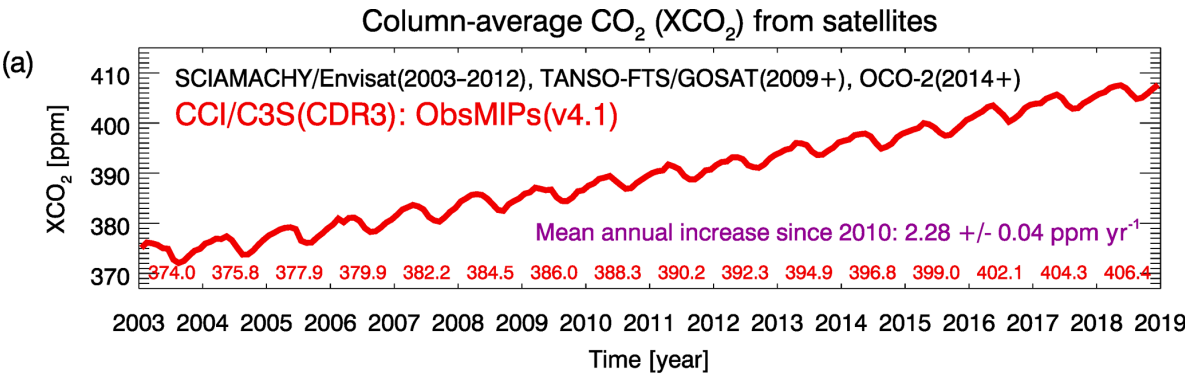

(b)

Global annual atmospheric $\mathrm{CO}_{2}$ growth rate

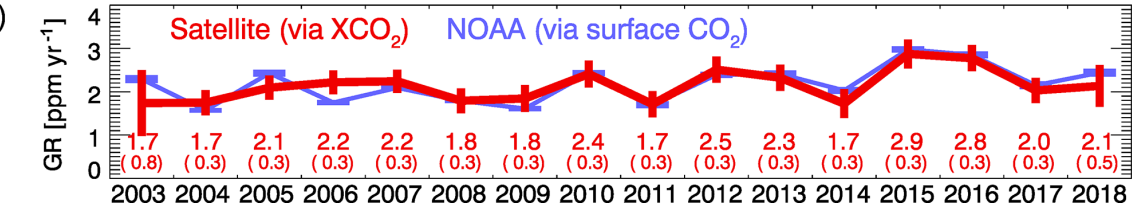

Figure 18. (a) Monthly values of the globally averaged $\mathrm{XCO}_{2}$ (over land) as computed from the OBS4MIPS version $4.1 \mathrm{XCO}_{2}$ data product. The corresponding annual mean $\mathrm{XCO}_{2}$ values are also listed. The increase during 2010-2018 is $2.28 \pm 0.04 \mathrm{ppm} \mathrm{yr}^{-1}$ as obtained via a linear fit. (b) Annual $\mathrm{XCO}_{2}$ growth rates (red, with $1 \sigma$ uncertainties; the corresponding numerical values are also listed with $1 \sigma$ uncertainty in brackets) and $\mathrm{CO}_{2}$ growth rates from NOAA (shown in blue) obtained from marine surface $\mathrm{CO}_{2}$ observations.

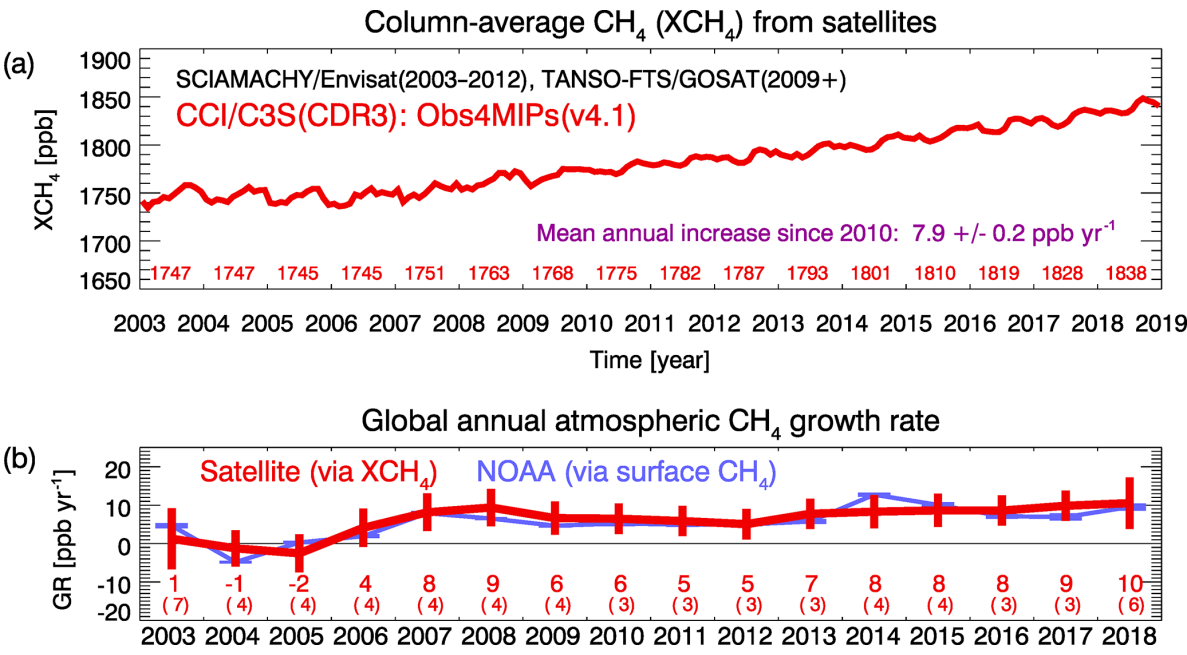

Figure 19. (a) Monthly values of the globally averaged $\mathrm{XCH}_{4}$ (over land) as computed from the OBS4MIPS version $4.1 \mathrm{XCH}_{4}$ data product. The corresponding annual mean $\mathrm{XCH}_{4}$ values are also listed. The increase during 2010-2018 is $7.9 \pm 0.2 \mathrm{ppb} \mathrm{yr}^{-1}$ as obtained via a linear fit. (b) Annual $\mathrm{XCH}_{4}$ growth rates (red, with $1 \sigma$ uncertainties; the corresponding numerical values are also listed with $1 \sigma$ uncertainty in brackets) and $\mathrm{CH}_{4}$ growth rates from NOAA (shown in blue) obtained from marine surface $\mathrm{CH}_{4}$ observations. 


\section{Appendix A}

In this appendix, detailed validation results are shown for the individual sensor and EMMA XCO ${ }_{2}$ and $\mathrm{XCH}_{4}$ Level 2 data products.

The comparison of the various $\mathrm{XCO}_{2}$ data products with TCCON $\mathrm{XCO}_{2}$ at 10 TCCON sites is shown in Fig. A1. These 10 TCCON sites fulfill the EMMA criteria in terms of a sufficiently large number of colocations as defined to obtain robust conclusions per site. The individual soundings of the EMMA $\mathrm{XCO}_{2}$ product are shown as white circles with a black border. As can be seen, they are located within (mostly close to the center of) the range of values of the individual sensor/algorithm $\mathrm{XCO}_{2}$ values, which is expected.

Figure A2 shows the comparison of the EMMA $\mathrm{XCH}_{4}$ product (white circles with a black border) and of the individual sensor $\mathrm{XCH}_{4}$ input products with TCCON $\mathrm{XCH}_{4}$ originating from the EMMA assessment method. As for the EMMA $\mathrm{XCO}_{2}$ product (Fig. A1), the EMMA $\mathrm{XCH}_{4}$ is located near the center of the clouds of $\mathrm{XCH}_{4}$ values, as expected. 


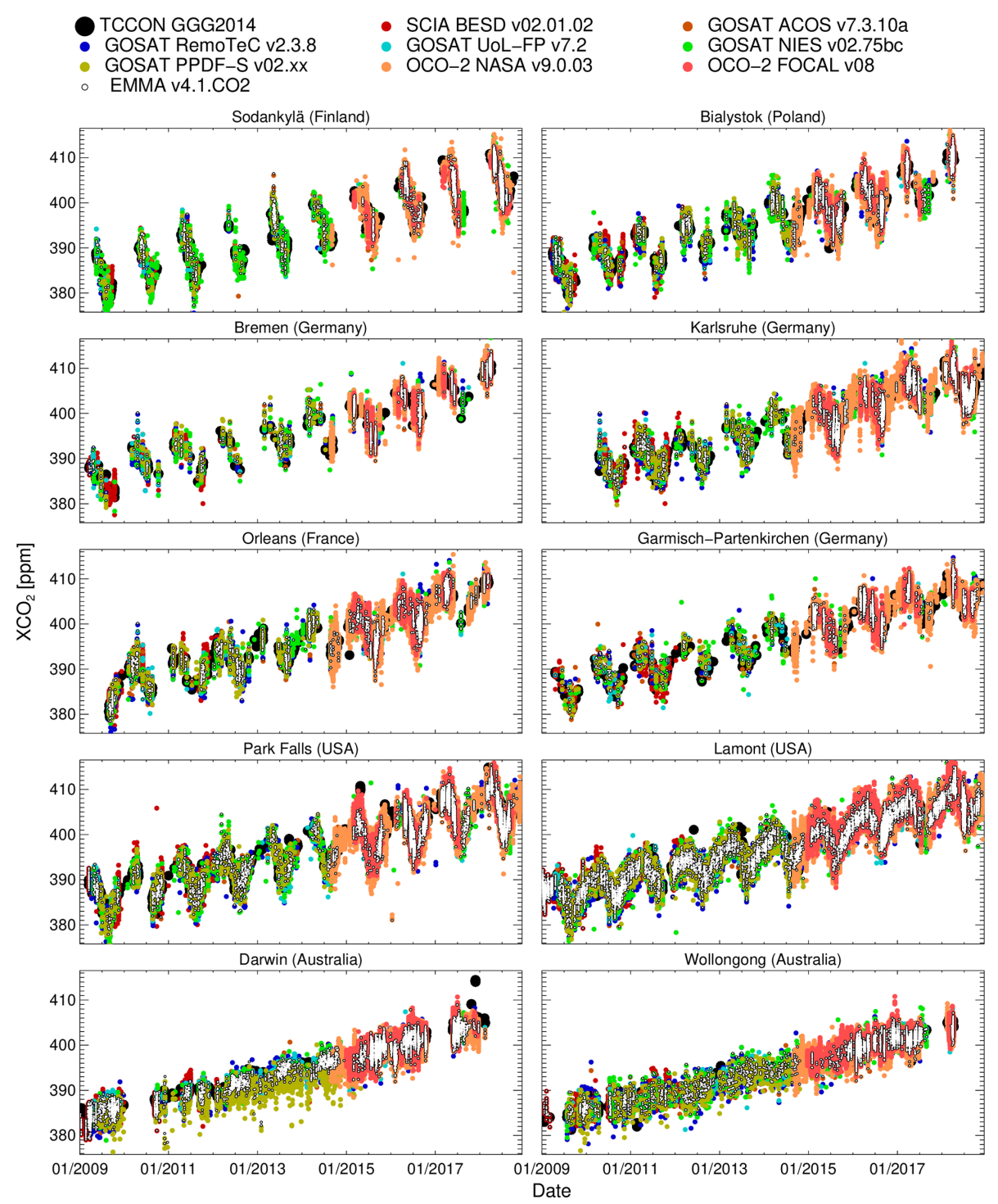

Figure A1. $\mathrm{XCO}_{2}$ time series at 10 TCCON sites during January 2009-December 2018 as obtained using the EMMA quality assessment method. TCCON GGG2014 $\mathrm{XCO}_{2}$ is shown as thick black dots, the individual satellite $\mathrm{L} 2$ input products are shown as colored dots, and the EMMA product is shown as white circles with black borders. The derived numerical values are listed in Table 4 . 


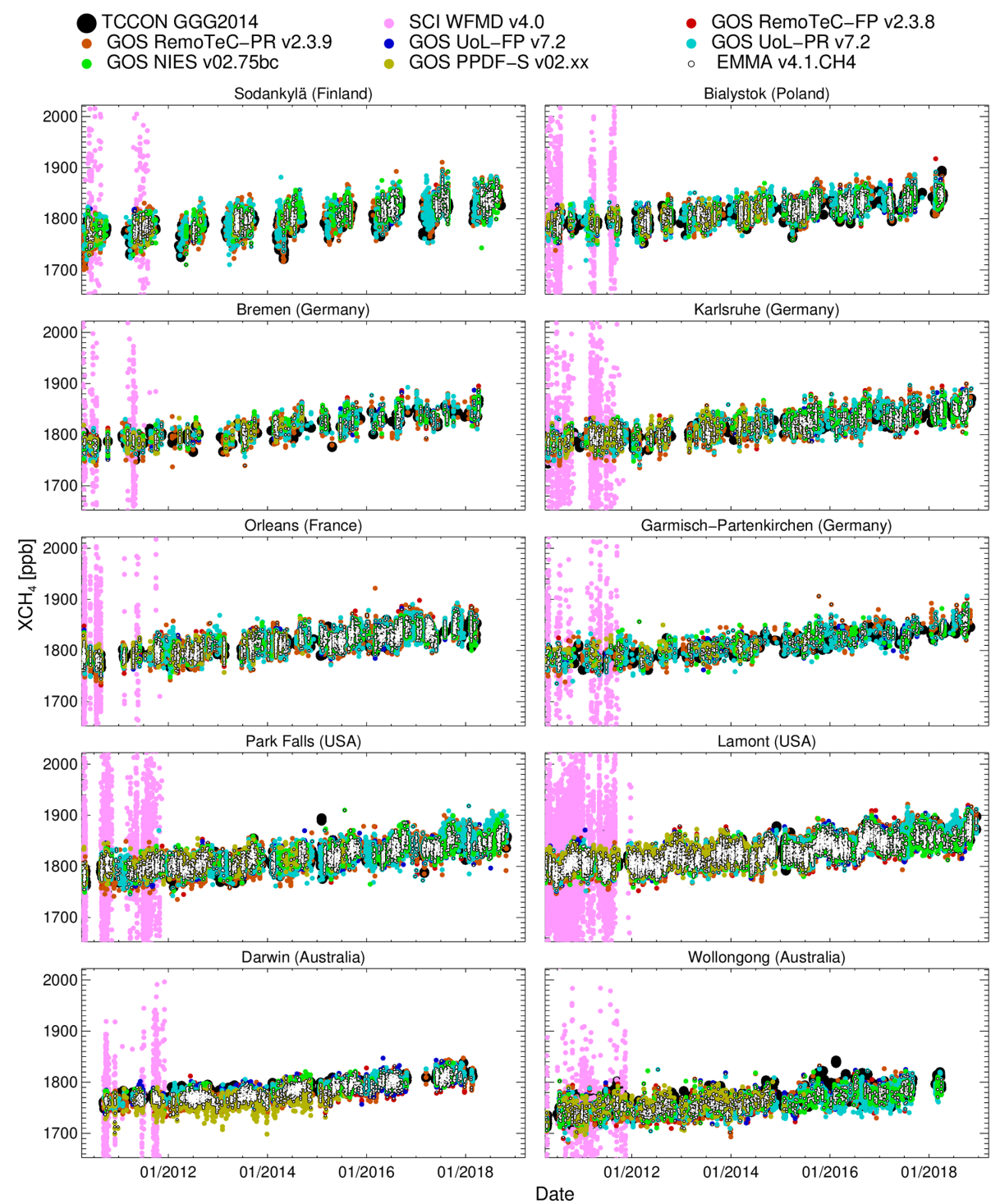

Figure A2. $\mathrm{XCH}_{4}$ time series at $10 \mathrm{TCCON}$ sites during April 2010-December 2018 as obtained using the EMMA quality assessment method. TCCON GGG2014 $\mathrm{XCH}_{4}$ is shown as thick black dots, the individual satellite $\mathrm{L} 2$ input products are shown as colored dots, and the EMMA product is shown as a white circles with black borders. The derived numerical values are listed in Table 7. 
Data availability. The EMMA and OBS4MIPS $\mathrm{XCO}_{2}$ and $\mathrm{XCH}_{4}$ version 4.1 data products (but also several data sets used as input; see data sets with CCI/C3S product ID in Tables 1 and 2) are available (from early 2020 onwards) via the Copernicus Climate Change Service (C3S, https://climate.copernicus.eu/, ECMWF, 2020a) Climate Data Store (CDS, https://cds.climate.copernicus.eu/, ECMWF, 2020b), including documentation such as the product user guides (http://www.iup.uni-bremen.de/carbon_ghg/ docs/C3S/CDR3_2003-2018/PUGS/C3S_D312b_Lot2.3.2.

3-v1.0_PUGS-GHG_MAIN_v3.1.pdf, Buchwitz et al., 2019c; http://www.iup.uni-bremen.de/carbon_ghg/docs/C3S/CDR3 2003-2018/PUGS/C3S_D312b_Lot2.3.2.3-v1.0_PUGS-GHG_ ANNEX-D_v3.1.pdf, Reuter et al., 2019d).

Author contributions. MR generated the EMMA and OBS4MIPS $\mathrm{XCO}_{2}$ and $\mathrm{XCH}_{4}$ version 4.1 data sets. MR and $\mathrm{MB}$ performed the data analysis. $\mathrm{MB}$ wrote the first version of the paper with support of MR. The following authors provided input data or expertise on data sets: MR, MB, OS, SN, HB, JPB, HBoe, ADN, JA, RJP, PS, LW, OPH, IA, AK, HS, KS, YY, IM, DC, CWO'D, JN, CP, TW, VAV, NMD, DWTG, RK, DP, FH, RS, YVT, KS, SR, MKS, MDM, DGF, LTI, CMR, CR, and DS. All authors contributed to significantly improve the paper.

Competing interests. The authors declare that they have no conflict of interest.

Acknowledgements. The generation of the EMMA Level 2 and OBS4MIPS Level 3 data sets and the corresponding data analysis has been funded primarily by the European Union (EU) via the Copernicus Climate Change Service (C3S, https://climate. copernicus.eu/, last access: 10 January 2020) managed by the European Centre for Medium-Range Weather Forecasts (ECMWF).

The work presented here strongly benefited from additional funding by the European Space Agency (ESA) via ESA's Climate Change Initiative (CCI, http://www.esa-ghg-cci.org/, last access: 10 January 2020) projects GHG-CCI/GHG-CCI+.

The further development of the FOCAL retrieval algorithm used to generate the OCO-2/FOCAL $\mathrm{XCO}_{2}$ input data product would not have been possible without cofunding from the European Union (EU) Horizon 2020 (H2020) research and innovation program projects CHE (grant agreement no. 776186) and VERIFY (grant agreement no. 776810). The generation of the XCO2_OBS4MIPS product also benefited from cofunding from EU H2020 project CCiCC (grant agreement no. 821003).

We thank several space agencies for making available satellite Level 1 (L1) input data: ESA/DLR for SCIAMACHY L1 data, JAXA for GOSAT Level 1B data, and NASA for the OCO-2 L1 data product. We also thank ESA for making the GOSAT L1 product available via the ESA Third Party Mission (TPM) archive.

We thank NIES for the operational GOSAT $\mathrm{XCO}_{2}$ and $\mathrm{XCH}_{4}$ Level 2 products (obtained from: https://data2.gosat.nies.go.jp/, last access: 4- September 2019) and the NASA team for the GOSAT and OCO-2 ACOS Level $2 \mathrm{XCO}_{2}$ products (the NASA GOSAT L2 data product was obtained from: https://oco2.gesdisc.eosdis. nasa.gov/data/GOSAT_TANSO_Level2/ACOS_L2_Lite_FP.7.3/, last access: 4 September 2019; the NASA OCO-2 data product was obtained from: https://oco2.gesdisc.eosdis.nasa.gov/ data/s4pa/OCO2_DATA/OCO2_L2_Lite_FP.9r/, last access: 4 September 2019).

TCCON data were obtained from the TCCON Data Archive, hosted by CaltechDATA, California Institute of Technology (https: //tccondata.org/, last access: 15 July 2019).

The TCCON stations Ascension Island, Bremen, Garmisch, Karlsruhe, and Ny-Ålesund have been supported by the German Bundesministerium für Wirtschaft und Energie (BMWi) via the DLR under grants 50EE1711A-E. We thank the ESA Ariane tracking station at North East Bay, Ascension Island, for hosting and local support. Nicholas M. Deutscher is supported by an ARC Future Fellowship, FT180100327. The TCCON site at Réunion island is operated by the Royal Belgian Institute for Space Aeronomy with financial support in 2014, 2015, 2016, 2017, 2018, and 2019 under the EU project ICOS-Inwire and the ministerial decree for ICOS (FR/35/IC2) and local activities supported by LACy/UMR8105 Université de La Réunion. The TCCON stations at Tsukuba and Burgos are supported in part by the GOSAT series project. Local support for Burgos is provided by the Energy Development Corporation (EDC, Philippines). The Paris TCCON site has received funding from Sorbonne Université, the French research center CNRS, the French space agency CNES, and Région Île-deFrance.

We also thank NOAA for access to the surface $\mathrm{CO}_{2}$ (file ftp://aftp.cmdl.noaa.gov/products/trends/co2/co2_gr_gl.txt; last access: 30 July 2019) and $\mathrm{CH}_{4}$ (file ftp://aftp.cmdl.noaa.gov/products/ trends/ch4/ch4_gr_gl.txt; last access: 30 July 2019) growth rate data sets. Output from NOAA's CarbonTracker has been used as input for the SECM2018 model. CarbonTracker CT2017 results are provided by NOAA ESRL, Boulder, Colorado, USA, from their website at: http://carbontracker.noaa.gov/ (last access: 4 September 2019).

We also thank Peter Bergamaschi for providing MACC-II project inversion system $\mathrm{CH}_{4}$ fields, which have been used as input for the SC4C2018 model.

Financial support. This research has been supported by the European Union (Copernicus Climate Change Service project C3S_312b_Lot2, via contract with DLR, contract no. D/565/67260504; CHE, grant agreement no. 776186; VERIFY, grant agreement no. 776810; CCiCC, grant agreement no. 821003) and the European Space Agency (ESA; grant no. Project GHG$\mathrm{CCI}+$ ).

The article processing charges for this open-access publication were covered by the University of Bremen.

Review statement. This paper was edited by John Worden and reviewed by Ray Nassar and two anonymous referees.

\section{References}

Alexe, M., Bergamaschi, P., Segers, A., Detmers, R., Butz, A., Hasekamp, O., Guerlet, S., Parker, R., Boesch, H., Frankenberg, 
C., Scheepmaker, R. A., Dlugokencky, E., Sweeney, C., Wofsy, S. C., and Kort, E. A.: Inverse modelling of $\mathrm{CH}_{4}$ emissions for 2010-2011 using different satellite retrieval products from GOSAT and SCIAMACHY, Atmos. Chem. Phys., 15, 113-133, https://doi.org/10.5194/acp-15-113-2015, 2015.

Basu, S., Guerlet, S., Butz, A., Houweling, S., Hasekamp, O., Aben, I., Krummel, P., Steele, P., Langenfelds, R., Torn, M., Biraud, S., Stephens, B., Andrews, A., and Worthy, D.: Global $\mathrm{CO}_{2}$ fluxes estimated from GOSAT retrievals of total column $\mathrm{CO}_{2}$, Atmos. Chem. Phys., 13, 8695-8717, https://doi.org/10.5194/acp13-8695-2013, 2013.

Boesch, H., Anand, J., Di Noia, A., Buchwitz, M., Somkuti, P., and Parker, R.: Product Quality Assessment Report (PQAR) ANNEX A for products CO2_GOS_OCFP, CH4_GOS_OCFP \& CH4_GOS_OCPR (v7.2, 2009-2018), Technical Report Copernicus Climate Change Service (C3S), version 3.1, 03-11-2019, 44 pp., available at: http://www.iup.uni-bremen.de/carbon_ ghg/docs/C3S/CDR3_2003-2018/PQAR/C3S_D312b_Lot2. 2.3.2-v1.0_PQAR-GHG_ANNEX-A_v3.1.pdf (last access: 10 January 2020), 2019.

Bovensmann, H., Burrows, J. P., Buchwitz, M., Frerick, J., Noël, S., Rozanov, V. V., Chance, K. V., and Goede, A. H. P.: SCIAMACHY - Mission objectives and measurement modes, J. Atmos. Sci., 56, 127-150, 1999.

Bril, A., Oshchepkov, S., and Yokota, T.: Application of a probability density function-based atmospheric light-scattering correction to carbon dioxide retrievals from GOSAT over-sea observations, Remote Sens. Environ., 117, 301-306, 2012.

Buchwitz, M., Reuter, M., Schneising, O., Boesch, H., Guerlet, S., Dils, B., Aben, I., Armante, R., Bergamaschi, P., Blumenstock, T., Bovensmann, H., Brunner, D., Buchmann, B., Burrows, J. P., Butz, A., Chédin, A., Chevallier, F., Crevoisier, C. D., Deutscher, N. M., Frankenberg, C., Hase, F., Hasekamp, O. P., Heymann, J., Kaminski, T., Laeng, A., Lichtenberg, G., De Mazière, M., Noël, S., Notholt, J., Orphal, J., Popp, C., Parker, R., Scholze, M., Sussmann, R., Stiller, G. P., Warneke, T., Zehner, C., Bril, A., Crisp, D., Griffith, D. W. T., Kuze, A., O'Dell, C., Oshchepkov, S., Sherlock, V., Suto, H., Wennberg, P., Wunch, D., Yokota, T., and Yoshida, Y.: The Greenhouse Gas Climate Change Initiative (GHG-CCI): comparison and quality assessment of near-surface-sensitive satellite-derived $\mathrm{CO}_{2}$ and $\mathrm{CH}_{4}$ global data sets, Remote Sens. Environ., 162, 344-362, https://doi.org/10.1016/j.rse.2013.04.024, 2015.

Buchwitz, M., Schneising, O., Reuter, M., Heymann, J., Krautwurst, S., Bovensmann, H., Burrows, J. P., Boesch, H., Parker, R. J., Somkuti, P., Detmers, R. G., Hasekamp, O. P., Aben, I., Butz, A., Frankenberg, C., and Turner, A. J.: Satellite-derived methane hotspot emission estimates using a fast data-driven method, Atmos. Chem. Phys., 17, 5751-5774, https://doi.org/10.5194/acp-17-5751-2017, 2017a.

Buchwitz, M., Reuter, M., Schneising, O., Hewson, W., Detmers, R. G., Boesch, H., Hasekamp, O. P., Aben, I., Bovensmann, H., Burrows, J. P., Butz, A., Chevallier, F., Dils, B., Frankenberg, C., Heymann, J., Lichtenberg, G., De Maziere, M., Notholt, J., Parker, R., Warneke, T., Zehner, C., Griffith, D. W. T., Deutscher, N. M., Kuze, A., Suto, H., and Wunch, D.: Global satellite observations of column-averaged carbon dioxide and methane: The GHG-CCI $\mathrm{XCO}_{2}$ and $\mathrm{XCH}_{4} \mathrm{CRDP} 3$ data set, Remote Sens. En- viron., 203, 276-295, https://doi.org/10.1016/j.rse.2016.12.027, 2017b.

Buchwitz, M., Reuter, M., Schneising, O., Noël, S., Gier, B., Bovensmann, H., Burrows, J. P., Boesch, H., Anand, J., Parker, R. J., Somkuti, P., Detmers, R. G., Hasekamp, O. P., Aben, I., Butz, A., Kuze, A., Suto, H., Yoshida, Y., Crisp, D., and O'Dell, C.: Computation and analysis of atmospheric carbon dioxide annual mean growth rates from satellite observations during 2003-2016, Atmos. Chem. Phys., 18, 17355-17370, https://doi.org/10.5194/acp-18-17355-2018, 2018.

Buchwitz, M., Reuter, M., Schneising-Weigel, O., Aben, I., Wu, L., Hasekamp, O. P., Boesch, H., Di Noia, A., Crevoisier, C., and Armante, R.: Product Quality Assessment Report (PQAR) Main document for Greenhouse Gas (GHG: $\mathrm{CO}_{2} \& \mathrm{CH}_{4}$ ) data set CDR 3 (2003-2018), Technical Report Copernicus Climate Change Service (C3S), version 3.1, 03-11-2019, 103 pp., availabel at: http://www.iup.uni-bremen.de/carbon_ghg/docs/ C3S/CDR3_2003-2018/PQAR/C3S_D312b_Lot2.2.3.2-v1.0_ PQAR-GHG_MAIN_v3.1.pdf (last access: 10 January 2020), 2019a.

Buchwitz, M., Reuter, M., Schneising-Weigel, O., Aben, I., Wu, L., Hasekamp, O. P., Boesch, H., Di Noia, A., Crevoisier, C., and Armante, R.: Algorithm Theoretical Basis Document (ATBD) - Main document for Greenhouse Gas (GHG: $\mathrm{CO}_{2}$ \& $\mathrm{CH}_{4}$ ) data set CDR 3 (2003-2018), Technical Report Copernicus Climate Change Service (C3S) (main document and 5 Annexes), version 3.1, 03-11-2019, 43 pp., available at: http://www.iup.uni-bremen.de/carbon_ghg/docs/C3S/CDR3_ 2003-2018/ATBD/C3S_D312b_Lot2.1.3.2-v1.0_ATBD-GHG_ MAIN_v3.1.pdf (last access: 10 January 2020), $2019 \mathrm{~b}$.

Buchwitz, M., Reuter, M., Schneising-Weigel, O., Aben, I., Wu, L., Hasekamp, O. P., Boesch, H., Di Noia, A., Crevoisier, C., and Armante, R.: Product User Guide and Specification (PUGS) - Main document for Greenhouse Gas (GHG: $\mathrm{CO}_{2} \& \mathrm{CH}_{4}$ ) data set CDR 3 (2003-2018), Technical Report Copernicus Climate Change Service (C3S), version 3.1, 03-11-2019, 97 pp., available at: http://www.iup.uni-bremen.de/carbon_ghg/docs/ C3S/CDR3_2003-2018/PUGS/C3S_D312b_Lot2.3.2.3-v1.0_ PUGS-GHG_MAIN_v3.1.pdf (last access: 10 January 2020), 2019c.

Burrows, J. P., Hölzle, E., Goede, A. P. H., Visser, H., and Fricke, W.: SCIAMACHY-Scanning Imaging Absorption Spectrometer for Atmospheric Chartography, Acta Astronaut., 35, 445-451, https://doi.org/10.1016/0094-5765(94)00278-t, 1995.

Butz, A., Hasekamp, O.P., Frankenberg, C., Vidot, J., and Aben, I.: $\mathrm{CH}_{4}$ retrievals from space-based solar backscatter measurements: Performance evaluation against simulated aerosol and cirrus loaded scenes, J. Geophys. Res., 115, D24302, https://doi.org/10.1029/2010JD014514, 2010.

Butz, A., Guerlet, S., Hasekamp, O., Schepers, D., Galli, A., Aben, I., Frankenberg, C., Hartmann, J.-M., Tran, H., Kuze, A., Keppel-Aleks, G., Toon, G., Wunch, D., Wennberg, P., Deutscher, N., Griffith, D., Macatangay, R., Messerschmidt, J., Notholt, J., and Warneke, T.: Toward accurate $\mathrm{CO}_{2}$ and $\mathrm{CH}_{4}$ observations from GOSAT, Geophys. Res. Lett., 38, L14812, https://doi.org/10.1029/2011GL047888, 2011.

Chevallier, F.: On the statistical optimality of $\mathrm{CO}_{2}$ atmospheric inversions assimilating $\mathrm{CO}_{2}$ column retrievals, Atmos. Chem. 
Phys., 15, 11133-11145, https://doi.org/10.5194/acp-15-111332015, 2015.

Chevallier, F., Palmer, P. I., Feng, L., Boesch, H., O’Dell, C. W., and Bousquet, P.: Towards robust and consistent regional $\mathrm{CO}_{2}$ flux estimates from in situ and space-borne measurements of atmospheric $\mathrm{CO}_{2}$, Geophys. Res. Lett., 41, 1065-1070, https://doi.org/10.1002/2013GL058772, 2014.

Cogan, A. J., Boesch, H., Parker, R. J., Feng, L., Palmer, P. I., Blavier, J.-F. L., Deutscher, N. M., Macatangay, R., Notholt, J., Roehl, C., Warneke, T., and Wunsch, D.: Atmospheric carbon dioxide retrieved from the Greenhouse gases Observing SATellite (GOSAT): Comparison with ground-based TCCON observations and GEOS-Chem model calculations, J. Geophys. Res., 117, D21301, https://doi.org/10.1029/2012JD018087, 2012.

Crisp, D., Atlas, R. M., Bréon, F.-M., Brown, L. R., Burrows, J. P., Ciais, P., Connor, B. J., Doney, S. C., Fung, I. Y., Jacob, D. J., Miller, C. E., O'Brien, D., Pawson, S., Randerson, J. T., Rayner, P., Salawitch, R. S., Sander, S. P., Sen, B., Stephens, G. L., Tans, P. P., Toon, G. C.,Wennberg, P. O.,Wofsy, S. C., Yung, Y. L., Kuang, Z., Chudasama, B., Sprague, G.,Weiss, P., Pollock, R., Kenyon, D., and Schroll, S.: The Orbiting Carbon Observatory (OCO) mission, Adv. Space Res., 34, 700-709, 2004.

De Mazière, M., Sha, M. K., Desmet, F., Hermans, C., Scolas, F., Kumps, N., Metzger, J.-M., Duflot, V., and Cammas, J.-P.: TCCON data from Réunion Island (RE), Release GGG2014R1. TCCON data archive, hosted by CaltechDATA, https://doi.org/10.14291/tccon.ggg2014.reunion01.R1, 2017.

Deutscher, N. M., Notholt, J., Messerschmidt, J., Weinzierl, C., Warneke, T., Petri, C., Grupe, P., and Katrynski, K.: TCCON data from Bialystok (PL), Release GGG2014R2. TCCON data archive, hosted by CaltechDATA, https://doi.org/10.14291/tccon.ggg2014.bialystok01.R2, 2019.

Dils, B., Buchwitz, M., Reuter, M., Schneising, O., Boesch, H., Parker, R., Guerlet, S., Aben, I., Blumenstock, T., Burrows, J. P., Butz, A., Deutscher, N. M., Frankenberg, C., Hase, F., Hasekamp, O. P., Heymann, J., De Mazière, M., Notholt, J., Sussmann, R., Warneke, T., Griffith, D., Sherlock, V., and Wunch, D.: The Greenhouse Gas Climate Change Initiative (GHG-CCI): comparative validation of GHG-CCI SCIAMACHY/ENVISAT and TANSO-FTS/GOSAT $\mathrm{CO}_{2}$ and $\mathrm{CH}_{4}$ retrieval algorithm products with measurements from the TCCON, Atmos. Meas. Tech., 7, 1723-1744, https://doi.org/10.5194/amt-7-1723-2014, 2014

ECMWF: Copernicus Climate Change Service (C3S) website, available at: https://climate.copernicus.eu/, last access: 10 January 2020a.

ECMWF: Copernicus Climate Data Store (CDS) website, available at: https://cds.climate.copernicus.eu/, last access: 10 January 2020 b.

Feist, D. G., Arnold, S. G., John, N., and Geibel, M. C.: TCCON data from Ascension Island (SH), Release GGG2014R0. TCCON data archive, hosted by CaltechDATA, https://doi.org/10.14291/tccon.ggg2014.ascension01.R0/1149285, 2014.

Ganesan, A. L., Rigby, M., Lunt, M. F., Parker, R. J., Boesch, H., Goulding, N., Umezawa. T., Zahn, A., Chatterjee, A., Prinn, R. G., Tiwari, Y. K., van der Schoot, M., and Krummel, P. B.: Atmospheric observations show accurate reporting and lit- tle growth in India's methane emissions, Nat. Commun., 8, 836, https://doi.org/10.1038/s41467-017-00994, 2017.

Gaubert, B., Stephens, B. B., Basu, S., Chevallier, F., Deng, F., Kort, E. A., Patra, P. K., Peters, W., Rödenbeck, C., Saeki, T., Schimel, D., Van der Laan-Luijkx, I., Wofsy, S., and Yin, Y.: Global atmospheric $\mathrm{CO}_{2}$ inverse models converging on neutral tropical land exchange, but disagreeing on fossil fuel and atmospheric growth rate, Biogeosciences, 16, 117-134, https://doi.org/10.5194/bg16-117-2019, 2019.

GCOS-154: Global Climate Observing System (GCOS), Systematic observation requirements for satellite-based products for climate, Supplemental details to the satellite-based component of the "Implementation Plan for the Global Observing System for Climate in Support of the UNFCCC (2010 update)", prepared by: World Meteorological Organization (WMO), Intergovernmental Oceanographic Commission, United Nations Environment Programme (UNEP), International Council for Science, Doc.: GCOS 154, availabel at: https://www.wmo.int/pages/prog/gcos/ Publications/gcos-154.pdf (last access: 21 February 2019), 2010.

GCOS-200: The Global Observing System for Climate: Implementation Needs, World Meteorological Organization (WMO), GCOS-200 (GOOS-214), 325 pp., available at: http://unfccc.int/files/science/workstreams/systematic_ observation/application/pdf/gcos_ip_10oct2016.pdf (last access: 21 February 2019), 2016.

Griffith, D. W., Velazco, V. A., Deutscher, N. M., Murphy, C., Jones, N. B., Wilson, S. R., Macatangay, R C., Kettlewell, G. C., Buchholz, R. R., and Riggenbach, M. O.: TCCON data from Wollongong, (AU), Release GGG2014R0. TCCON data archive, hosted by Caltech-DATA, https://doi.org/10.14291/tccon.ggg2014.wollongong01.R0/1149291, 2014a.

Griffith, D. W. T., Deutscher, N. M., Velazco, V. A.,Wennberg, P. O., Yavin, Y., Keppel-Aleks, G.,Washenfelder, R. A., Toon, G. C., Blavier, J.-F., Murphy, C., Jones, N. B., Kettlewell, G. C., Connor, B. J., Macatangay, R. C., Roehl, C., Ryczek, M., Glowacki, J., Culgan, T., and Bryant, G. W.: TCCON data from Darwin (AU), Release GGG2014R0. TCCON data archive, hosted by CaltechDATA https://doi.org/10.14291/tccon.ggg2014.darwin01.R0/1149290, 2014b.

Hase, F., Blumenstock, T., Dohe, S., Groß, J., and Kiel, M.: TCCON data from Karlsruhe (DE), Release GGG2014R1. TCCON data archive, hosted by CaltechDATA, https://doi.org/10.14291/tccon.ggg2014.karlsruhe01.R1/1182416, 2015.

Hayman, G. D., O’Connor, F. M., Dalvi, M., Clark, D. B., Gedney, N., Huntingford, C., Prigent, C., Buchwitz, M., Schneising, O., Burrows, J. P., Wilson, C., Richards, N., and Chipperfield, M.: Comparison of the HadGEM2 climate-chemistry model against in situ and SCIAMACHY atmospheric methane data, Atmos. Chem. Phys., 14, 13257-13280, https://doi.org/10.5194/acp-1413257-2014, 2014.

Hedelius, J. K., Parker, H., Wunch, D., Roehl, C. M., Viatte, C., Newman, S., Toon, G. C., Podolske, J. R., Hillyard, P. W., Iraci, L. T., Dubey, M. K., and Wennberg, P. O.: Intercomparability of $\mathrm{X}_{\mathrm{CO}_{2}}$ and $\mathrm{X}_{\mathrm{CH}_{4}}$ from the United States TCCON sites, Atmos. Meas. Tech., 10, 1481-1493, https://doi.org/10.5194/amt10-1481-2017, 2017. 
Heymann, J., Reuter, M., Hilker, M., Buchwitz, M., Schneising, O., Bovensmann, H., Burrows, J. P., Kuze, A., Suto, H., Deutscher, N. M., Dubey, M. K., Griffith, D. W. T., Hase, F., Kawakami, S., Kivi, R., Morino, I., Petri, C., Roehl, C., Schneider, M., Sherlock, V., Sussmann, R., Velazco, V. A., Warneke, T., and Wunch, D.: Consistent satellite $\mathrm{XCO}_{2}$ retrievals from SCIAMACHY and GOSAT using the BESD algorithm, Atmos. Meas. Tech., 8, 2961-2980, https://doi.org/10.5194/amt-8-2961-2015, 2015.

Hollmann, R., Merchant, C. J., Saunders, R., Downy, C., Buchwitz, M., Cazenave, A., Chuvieco, E., Defourny, P., de Leeuw, G., Forsberg, R., Holzer-Popp, T., Paul, F., Sandven, S., Sathyendranath, S., van Roozendael, M., and Wagner, W.: The ESA Climate Change Initiative: satellite data records for essential climate variables, B. Am. Meteorol. Soc., 94, 1541-1552, https://doi.org/10.1175/BAMS-D-11-00254.1, 2013.

Houweling, S., Baker, D., Basu, S., Boesch, H., Butz, A., Chevallier, F., Deng, F., Dlugokencky, E. J., Feng, L., Ganshin, A., Hasekamp, O., Jones, D., Maksyutov, S., Marshall, J., Oda, T., O’Dell, C. W., Oshchepkov, S., Palmer, P. I., Peylin, P., Poussi, Z., Reum, F., Takagi, H., Yoshida, Y., and Zhuralev, R.: An intercomparison of inverse models for estimating sources and sinks of $\mathrm{CO}_{2}$ using GOSAT measurements, J. Geophys. Res.-Atmos., 120, 5253-5266, https://doi.org/10.1002/2014JD022962, 2015.

Howarth, R. W.: Ideas and perspectives: is shale gas a major driver of recent increase in global atmospheric methane?, Biogeosciences, 16, 3033-3046, https://doi.org/10.5194/bg-16-30332019, 2019.

Hu, H., Landgraf, J., Detmers, R., Borsdorff, T., Aan de Brugh, J., Aben, I., Butz, A., and Hasekamp, O.: Toward Global Mapping of Methane With TROPOMI: First Results and Intersatellite Comparison to GOSAT, Geophys. Res. Lett., 45, 3682-3689, https://doi.org/10.1002/2018GL077259, 2018.

IPCC: Climate Change 2013: The Physical Science Basis, Working Group I Contribution to the Fifth Assessment Report of the Intergovernmental Report on Climate Change, Cambridge University Press, availabel at: http://www.ipcc.ch/report/ar5/wg1/ (last access: 21 February 2019), 2013.

Iraci, L., Podolske, J., Hillyard, P., Roehl, C., Wennberg, P. O., Blavier, J.-F., Landeros, J., Allen, N., Wunch, D., Zavaleta, J., Quigley, E., Osterman, G., Albertson, R., Dunwoody, K., and Boyden, H.: TCCON data from Edwards (US), Release GGG2014.R1. TCCON data archive, hosted by CaltechDATA, https://doi.org/10.14291/tccon.ggg2014.edwards01.R1/1255068, 2014.

Kaminski, T., Scholze, M., Voßbeck, M., Knorr, W., Buchwitz, M., and Reuter, M.: Constraining a terrestrial biosphere model with remotely sensed atmospheric carbon dioxide, Remote Sens. Environ., 203, 109-124, 2017.

Kiel, M., O’Dell, C. W., Fisher, B., Eldering, A., Nassar, R., MacDonald, C. G., and Wennberg, P. O.: How bias correction goes wrong: measurement of $\mathrm{X}_{\mathrm{CO}_{2}}$ affected by erroneous surface pressure estimates, Atmos. Meas. Tech., 12, 2241-2259, https://doi.org/10.5194/amt-12-2241-2019, 2019.

Kivi, R. and Heikkinen, P.: Fourier transform spectrometer measurements of column $\mathrm{CO}_{2}$ at Sodankylä, Finland, Geosci. Instrum. Method. Data Syst., 5, 271-279, https://doi.org/10.5194/gi-5-271-2016, 2016.

Kivi, R., Heikkinen, P., and Kyrö, E.: TCCON data from Sodankylä (FI), Release GGG2014R0.
TCCON data archive, hosted by CaltechDATA, https://doi.org/10.14291/tccon.ggg2014.sodankyla01.R0/1149280, 2014.

Kuze, A., Suto, H., Shiomi, K., Kawakami, S., Tanaka, M., Ueda, Y., Deguchi, A., Yoshida, J., Yamamoto, Y., Kataoka, F., Taylor, T. E., and Buijs, H. L.: Update on GOSAT TANSOFTS performance, operations, and data products after more than 6 years in space, Atmos. Meas. Tech., 9, 2445-2461, https://doi.org/10.5194/amt-9-2445-2016, 2016.

Lauer, A., Eyring, V., Righi, M., Buchwitz, M., Defourny, P., Evaldsson, M., Friedlingstein, P., de Jeu, R., de Leeuw, G., Loew, A., Merchant, C. J., Müller, B., Popp, T., Reuter, M., Sandven, S., Senftleben, D., Stengel, M., Van Roozendael, M., Wenzel, S., and Willén, U.: Benchmarking CMIP5 models with a subset of ESA CCI Phase 2 data using the ESMValTool, Remote Sens. Environ., 203, 9-39, https://doi.org/10.1016/j.rse.2017.01.007, 2017.

Le Quéré, C., Andrew, R. M., Friedlingstein, P., Sitch, S., Pongratz, J., Manning, A. C., Korsbakken, J. I., Peters, G. P., Canadell, J. G., Jackson, R. B., Boden, T. A., Tans, P. P., Andrews, O. D., Arora, V. K., Bakker, D. C. E., Barbero, L., Becker, M., Betts, R. A., Bopp, L., Chevallier, F., Chini, L. P., Ciais, P., Cosca, C. E., Cross, J., Currie, K., Gasser, T., Harris, I., Hauck, J., Haverd, V., Houghton, R. A., Hunt, C. W., Hurtt, G., Ilyina, T., Jain, A. K., Kato, E., Kautz, M., Keeling, R. F., Klein Goldewijk, K., Körtzinger, A., Landschützer, P., Lefèvre, N., Lenton, A., Lienert, S., Lima, I., Lombardozzi, D., Metzl, N., Millero, F., Monteiro, P. M. S., Munro, D. R., Nabel, J. E. M. S., Nakaoka, S., Nojiri, Y., Padin, X. A., Peregon, A., Pfeil, B., Pierrot, D., Poulter, B., Rehder, G., Reimer, J., Rödenbeck, C., Schwinger, J., Séférian, R., Skjelvan, I., Stocker, B. D., Tian, H., Tilbrook, B., Tubiello, F. N., van der Laan-Luijkx, I. T., van der Werf, G. R., van Heuven, S., Viovy, N., Vuichard, N., Walker, A. P., Watson, A. J., Wiltshire, A. J., Zaehle, S., and Zhu, D.: Global Carbon Budget 2017, Earth Syst. Sci. Data, 10, 405-448, https://doi.org/10.5194/essd-10-405-2018, 2018.

Liu, J., Bowman, K. W., Schimel, D. S., Parazoo, N. C., Jiang, Z., Lee, M., Bloom, A. A., Wunch, D., Frankenberg, C., Sun, Y., O’Dell, C. W., Gurney, K. R., Menemenlis, D., Gierach, M., Crisp, D., and Eldering, A.: Contrasting carbon cycle responses of the tropical continents to the 2015-2016 El Niño, Science, 358, eaam5690, https://doi.org/10.1126/science.aam5690, 2017.

Maasakkers, J. D., Jacob, D. J., Sulprizio, M. P., Scarpelli, T. R., Nesser, H., Sheng, J.-X., Zhang, Y., Hersher, M., Bloom, A. A., Bowman, K. W., Worden, J. R., Janssens-Maenhout, G., and Parker, R. J.: Global distribution of methane emissions, emission trends, and $\mathrm{OH}$ concentrations and trends inferred from an inversion of GOSAT satellite data for 2010-2015, Atmos. Chem. Phys., 19, 7859-7881, https://doi.org/10.5194/acp-197859-2019, 2019.

Miller, S. M., Michalak, A. M., Detmers, R. G., Hasekamp, O. P., Bruhwiler, L. M. P., and Schwietzke, S.: China's coal mine methane regulations have not curbed growing emissions, Nat. Commun., 10, 303, 2019.

Morino, I., Matsuzaki, T., and Shishime, A.: TCCON data from Tsukuba, Ibaraki (JP), 125HR, Release GGG2014R2. TCCON data archive, hosted by CaltechDATA, https://doi.org/10.14291/tccon.ggg2014.tsukuba02.R2, 2018a. 
Morino, I., Velazco, V. A., Hori, A., Uchino, O., and Griffith, D. W. T.: TCCON data from Burgos, Ilocos Norte (PH), Release GGG2014.R0. TCCON data archive, hosted by CaltechDATA, https://doi.org/10.14291/tccon.ggg2014.burgos01.R0, 2018b.

Nassar, R., Hill, T. G., McLinden, C. A., Wunch, D., Jones, D. B. A., and Crisp, D.: Quantifying $\mathrm{CO}_{2}$ emissions from individual power plants from space, Geophys. Res. Lett., 44, 10045-10053, https://doi.org/10.1002/2017GL074702, 2017.

Nisbet, E. G., Manning, M. R., Dlugokencky, E. J., Fisher, R. E., Lowry, D., Michel, S. E., Lund Myhre, C., Platt, S. M., Allen, G., Bousquet, P., Brownlow, R., Cain, M., France, J. L., Hermansen, O., Hossaini, R., Jones, A. E., Levin, I., Manning, A. C., Myhre, G., Pyle, J. A., Vaughn, B., Warwick, N. J., and White, J. W. C.: Very strong atmospheric methane growth in the four years 20142017: Implications for the Paris Agreement, Global Biogeochem. Cy., 33, 318-342, https://doi.org/10.1029/2018GB006009, 2019.

Notholt, J., Schrems, O., Warneke, T., Deutscher, N. M., Weinzierl, C., Palm, M., and Buschmann, M.: TCCON data from Ny-Ålesund, Spitzbergen (NO), Release GGG2014R1. TCCON data archive, hosted by CaltechDATA, https://doi.org/10.14291/tccon.ggg2014.nyalesund01.R1, 2019a.

Notholt, J., Petri, C., Warneke, T., Deutscher, N., Buschmann, M., Weinzierl, C., Macatangay, R., and Gruppe, P.: TCCON data from Bremen (DE), Release GGG2014R1. TCCON data archive, hosted by CaltechDATA, https://doi.org/10.14291/tccon.ggg2014.bremen01.R1, 2019b.

O'Dell, C. W., Connor, B., Bösch, H., O'Brien, D., Frankenberg, C., Castano, R., Christi, M., Eldering, D., Fisher, B., Gunson, M., McDuffie, J., Miller, C. E., Natraj, V., Oyafuso, F., Polonsky, I., Smyth, M., Taylor, T., Toon, G. C., Wennberg, P. O., and Wunch, D.: The ACOS CO2 retrieval algorithm - Part 1: Description and validation against synthetic observations, Atmos. Meas. Tech., 5, 99-121, https://doi.org/10.5194/amt-5-99-2012, 2012.

O’Dell, C. W., Eldering, A., Wennberg, P. O., Crisp, D., Gunson, M. R., Fisher, B., Frankenberg, C., Kiel, M., Lindqvist, H., Mandrake, L., Merrelli, A., Natraj, V., Nelson, R. R., Osterman, G. B., Payne, V. H., Taylor, T. E., Wunch, D., Drouin, B. J., Oyafuso, F., Chang, A., McDuffie, J., Smyth, M., Baker, D. F., Basu, S., Chevallier, F., Crowell, S. M. R., Feng, L., Palmer, P. I., Dubey, M., García, O. E., Griffith, D. W. T., Hase, F., Iraci, L. T., Kivi, R., Morino, I., Notholt, J., Ohyama, H., Petri, C., Roehl, C. M., Sha, M. K., Strong, K., Sussmann, R., Te, Y., Uchino, O., and Velazco, V. A.: Improved retrievals of carbon dioxide from Orbiting Carbon Observatory-2 with the version 8 ACOS algorithm, Atmos. Meas. Tech., 11, 6539-6576, https://doi.org/10.5194/amt11-6539-2018, 2018.

Parker, R., Boesch, H., Cogan, A., Fraser, A., Feng, L, Palmer, P., Messerschmidt, J., Deutscher, N., Griffth, D., Notholt, J., Wennberg, P. O., and Wunch, D.: Methane Observations from the Greenhouse gases Observing SATellite: Comparison to groundbased TCCON data and Model Calculations, Geophys. Res. Lett., 38, L15807, https://doi.org/10.1029/2011GL047871, 2011.

Peters, W., Jacobson, A. R., Sweeney, C., Andrews, A. E., Con-way, T. J., Masarie, K., Miller, J. B., Bruhwiler, L. M. P. Pétron, G., Hirsch, A. I., Worthy, D. E. J., van der Werf, G. R.,Randerson, J. T., Wennberg, P. O., Krol, M. C., and Tans, P. P.: An atmospheric perspective on North American carbon dioxide exchange: CarbonTracker, P. Natl. Acad. Sci. USA, 104, 1892518930, https://doi.org/10.1073/pnas.0708986104, 2007.
Reuter, M., Buchwitz, M., Schneising, O., Heymann, J., Bovensmann, H., and Burrows, J. P.: A method for improved SCIAMACHY $\mathrm{CO}_{2}$ retrieval in the presence of optically thin clouds, Atmos. Meas. Tech., 3, 209-232, https://doi.org/10.5194/amt-3209-2010, 2010.

Reuter, M., Bovensmann, H., Buchwitz, M., Burrows, J. P., Connor, B. J., Deutscher, N. M., Griffith, D. W. T., Heymann, J., Keppel-Aleks, G., Messerschmidt, J., Notholt, J., Petri, C., Robinson, J., Schneising, O., Sherlock, V., Velazco, V., Warneke, W., Wennberg, P. O., and Wunch, D.: Retrieval of atmospheric $\mathrm{CO}_{2}$ with enhanced accuracy and precision from SCIAMACHY: Validation with FTS measurements and comparison with model results, J. Geophys. Res., 116, D04301, https://doi.org/10.1029/2010JD015047, 2011.

Reuter, M., Buchwitz, M., Schneising, O., Hase, F., Heymann, J., Guerlet, S., Cogan, A. J., Bovensmann, H., and Burrows, J. P.: A simple empirical model estimating atmospheric $\mathrm{CO}_{2}$ background concentrations, Atmos. Meas. Tech., 5, 1349-1357, https://doi.org/10.5194/amt-5-1349-2012, 2012.

Reuter, M., Bösch, H., Bovensmann, H., Bril, A., Buchwitz, M., Butz, A., Burrows, J. P., O’Dell, C. W., Guerlet, S., Hasekamp, O., Heymann, J., Kikuchi, N., Oshchepkov, S., Parker, R., Pfeifer, S., Schneising, O., Yokota, T., and Yoshida, Y.: A joint effort to deliver satellite retrieved atmospheric $\mathrm{CO}_{2}$ concentrations for surface flux inversions: the ensemble median algorithm EMMA, Atmos. Chem. Phys., 13, 1771-1780, https://doi.org/10.5194/acp-13-1771-2013, 2013.

Reuter, M., Buchwitz, M., Hilker, M., Heymann, J., Schneising, O., Pillai, D., Bovensmann, H., Burrows, J. P., Bösch, H., Parker, R., Butz, A., Hasekamp, O., O’Dell, C. W., Yoshida, Y., Gerbig, C., Nehrkorn, T., Deutscher, N. M., Warneke, T., Notholt, J., Hase, F., Kivi, R., Sussmann, R., Machida, T., Matsueda, H., and Sawa, Y.: Satellite-inferred European carbon sink larger than expected, Atmos. Chem. Phys., 14, 13739-13753, https://doi.org/10.5194/acp-14-13739-2014, 2014a.

Reuter, M., Buchwitz, M., Hilboll, A., Richter, A., Schneising, O., Hilker, M., Heymann, J., Bovensmann, H., and Burrows, J. P.: Decreasing emissions of NOx relative to $\mathrm{CO}_{2}$ in East Asia inferred from satellite observations, Nat. Geosci., 7, 792-795, https://doi.org/10.1038/ngeo2257, 2014b.

Reuter, M., Buchwitz, M., Schneising, O., Noël, S., Rozanov, V., Bovensmann, H., and Burrows, J. P.: A Fast Atmospheric Trace Gas Retrieval for Hyperspectral Instruments Approximating Multiple Scattering - Part 1: Radiative Transfer and a Potential OCO-2 $\mathrm{XCO}_{2}$ Retrieval Setup, Remote Sens., 9, 1159, https://doi.org/10.3390/rs9111159, 2017a.

Reuter, M., Buchwitz, M., Schneising, O., Noël, S., Bovensmann, H., and Burrows, J. P.: A Fast Atmospheric Trace Gas Retrieval for Hyperspectral Instruments Approximating Multiple Scattering - Part 2: Application to $\mathrm{XCO}_{2}$ Retrievals from OCO-2, Remote Sens., 9, 1102, https://doi.org/10.3390/rs9111102, 2017b.

Reuter, M., Buchwitz, M., Schneising, O., Krautwurst, S., O’Dell, C. W., Richter, A., Bovensmann, H., and Burrows, J. P.: Towards monitoring localized $\mathrm{CO}_{2}$ emissions from space: colocated regional $\mathrm{CO}_{2}$ and $\mathrm{NO}_{2}$ enhancements observed by the OCO-2 and S5P satellites, Atmos. Chem. Phys., 19, 9371-9383, https://doi.org/10.5194/acp-19-9371-2019, 2019a.

Reuter, M., Buchwitz, M., and Schneising-Weigel, O.: Algorithm Theoretical Basis Document (ATBD) - ANNEX D for 
products XCO2_EMMA, XCH4_EMMA, XCO2_OBS4MIPS, XCH4_OBS4MIPS (v4.1, 2003-2018), Technical Report Copernicus Climate Change Service (C3S), version 3.1, 03-11-2019, 37 pp., available at: http://www.iup.uni-bremen.de/carbon_ ghg/docs/C3S/CDR3_2003-2018/ATBD/C3S_D312b_Lot2.

1.3.2-v1.0_ATBD-GHG_ANNEX-D_v3.1.pdf (last access: 10 January 2020), 2019b.

Reuter, M., Buchwitz, M., and Schneising-Weigel, O.: Product Quality Assessment Report (PQAR) - ANNEX D for products XCO2_EMMA, XCH4_EMMA, XCO2_OBS4MIPS, XCH4_OBS4MIPS (v4.1, 2003-2018), Technical Report Copernicus Climate Change Service (C3S), version 3.1, 03-11-2019, 37 pp., available at: http://www.iup.uni-bremen.de/carbon_ ghg/docs/C3S/CDR3_2003-2018/PQAR/C3S_D312b_Lot2. 2.3.2-v1.0_PQAR-GHG_ANNEX-D_v3.1.pdf (last access: 10 January 2020), 2019c.

Reuter, M., Buchwitz, M., and Schneising-Weigel, O.: Product User Guide and Specification (PUGS) - ANNEX D for products XCO2_EMMA, XCH4_EMMA, XCO2_OBS4MIPS, XCH4_OBS4MIPS (v4.1, 2003-2018), Technical Report Copernicus Climate Change Service (C3S), version 3.1, 03-11-2019, 22 pp., available at: http://www.iup.uni-bremen.de/carbon_ ghg/docs/C3S/CDR3_2003-2018/PUGS/C3S_D312b_Lot2. 3.2.3-v1.0_PUGS-GHG_ANNEX-D_v3.1.pdf (last access: 10 January 2020), 2019d.

Rodgers, C. D.: Inverse Methods for Atmospheric Sounding: Theory and Practice, World Scientific Publishing, 2000.

Schaefer, H.: On the Causes and Consequences of Recent Trends in Atmospheric Methane, Curr. Clim. Change Rep., 5, 259-274, https://doi.org/10.1007/s40641-019-00140-z, 2019.

Schneising, O., Buchwitz, M., Reuter, M., Heymann, J., Bovensmann, H., and Burrows, J. P.: Long-term analysis of carbon dioxide and methane column-averaged mole fractions retrieved from SCIAMACHY, Atmos. Chem. Phys., 11, 28632880, https://doi.org/10.5194/acp-11-2863-2011, 2011.

Schneising, O., Reuter, M., Buchwitz, M., Heymann, J., Bovensmann, H., and Burrows, J. P.: Terrestrial carbon sink observed from space: variation of growth rates and seasonal cycle amplitudes in response to interannual surface temperature variability, Atmos. Chem. Phys., 14, 133-141, https://doi.org/10.5194/acp14-133-2014, 2014a.

Schneising, O., Burrows, J. P., Dickerson, R. R., Buchwitz, M., Reuter, M., and Bovensmann, H.: Remote sensing of fugitive methane emissions from oil and gas production in North American tight geologic formations, Earth's Future, 2, https://doi.org/10.1002/2014EF000265, 2014b.

Schneising, O., Buchwitz, M., Reuter, M., Bovensmann, H., Burrows, J. P., Borsdorff, T., Deutscher, N. M., Feist, D. G., Griffith, D. W. T., Hase, F., Hermans, C., Iraci, L. T., Kivi, R., Landgraf, J., Morino, I., Notholt, J., Petri, C., Pollard, D. F., Roche, S., Shiomi, K., Strong, K., Sussmann, R., Velazco, V. A., Warneke, T., and Wunch, D.: A scientific algorithm to simultaneously retrieve carbon monoxide and methane from TROPOMI onboard Sentinel-5 Precursor, Atmos. Meas. Tech., 12, 67716802, https://doi.org/10.5194/amt-12-6771-2019, 2019.

Sheng, J.-X., Jacob, D. J., Turner, A. J., Maasakkers, J. D., Benmergui, J., Bloom, A. A., Arndt, C., Gautam, R., Zavala-Araiza, D., Boesch, H., and Parker, R. J.: 2010-2016 methane trends over Canada, the United States, and Mexico observed by the GOSAT satellite: contributions from different source sectors, Atmos. Chem. Phys., 18, 12257-12267, https://doi.org/10.5194/acp-1812257-2018, 2018.

Sherlock, V., Connor, B., Robinson, J., Shiona, H., Smale, D., and Pollard, D. F.: TCCON data from Lauder (NZ), 125HR, Release GGG2014R0. TCCON data archive, hosted by CaltechDATA, https://doi.org/10.14291/tccon.ggg2014.lauder02.R0/1149298, 2014.

Shiomi, K., Kawakami, S., Ohyama, H., Arai, K., Okumura, H., Taura, C., Fukamachi, T., and Sakashita, M.: TCCON data from Saga (JP), Release GGG2014R0. TCCON data archive, hosted by CaltechDATA, https://doi.org/10.14291/tccon.ggg2014.saga01.R0/1149283, 2014.

Strong, K., Roche, S., Franklin, J. E., Mendonca, J., Lutsch, E., Weaver, D., Fogal, P. F., Drummond, J. R., Batchelor, R., and Lindenmaier, R.: TCCON data from Eureka (CA), Release GGG2014R3. TCCON data archive, hosted by CaltechDATA, https://doi.org/10.14291/tccon.ggg2014.eureka01.R3, 2019.

Sussmann, R. and Rettinger, M.: TCCON data from Garmisch (DE), Release GGG2014R2. TCCON data archive, hosted by CaltechDATA, https://doi.org/10.14291/tccon.ggg2014.garmisch01.R2, 2018.

Té, Y., Jeseck, P., and Janssen, C.: TCCON data from Paris (FR), Release GGG2014R0. TCCON data archive, hosted by CaltechDATA, https://doi.org/10.14291/tccon.ggg2014.paris01.R0/1149279, 2014.

Turner, A. J., Jacob, D. J., Wecht, K. J., Maasakkers, J. D., Lundgren, E., Andrews, A. E., Biraud, S. C., Boesch, H., Bowman, K. W., Deutscher, N. M., Dubey, M. K., Griffith, D. W. T., Hase, F., Kuze, A., Notholt, J., Ohyama, H., Parker, R., Payne, V. H., Sussmann, R., Sweeney, C., Velazco, V. A., Warneke, T., Wennberg, P. O., and Wunch, D.: Estimating global and North American methane emissions with high spatial resolution using GOSAT satellite data, Atmos. Chem. Phys., 15, 7049-7069, https://doi.org/10.5194/acp-15-7049-2015, 2015.

Turner, A. J., Frankenberg, C., and Kort, E. A.: Interpreting contemporary trends in atmospheric methane, P. Natl. Acad. Sci. USA, 116, 2805-2813, https://doi.org/10.1073/pnas.1814297116, 2019.

Veefkind, J. P., Aben, I., McMullan, K., Förster, H., De Vries, J., Otter, G., Claas, J., Eskes, H. J., De Haan, J. F., Kleipool, Q., Van Weele, M., Hasekamp, O., Hoogeveen, R., Landgraf, J., Snel, R., Tol, P.,Ingmann, P., Voors, R., Kruizinga, B., Vink, R., Visser, H., and Levelt, P. F.: TROPOMI on the ESA Sentinel-5 Precursor: A GMES mission for global observations of the atmospheric composition for climate, air quality and ozone layer applications, Remote Sens. Environ., 120, 70-83, 2012.

Velazco V. A., Morino, I., Uchino, O., Hori, A., Kiel, M., Bukosa, B., Deutscher, N. M., Sakai, T., Nagai, T., Bagtasa, G., Izumi, T., Yoshida, Y., and Griffith, D. W. T.: TCCON Philippines: First Measurement Results, Satellite Data and Model Comparisons in Southeast Asia, Remote Sens., 9, 1228, https://doi.org/10.3390/rs9121228, 2017.

Warneke, T., Messerschmidt, J., Notholt, J.,Weinzierl, 5 C., Deutscher, N. M., Petri, C., Grupe, P., Vuillemin, C., Truong, F., Schmidt, M., Ramonet, M., and Parmentier, E.: TCCON data from Orléans (FR), Release 
GGG2014R1. TCCON data archive, hosted by CaltechDATA, https://doi.org/10.14291/tccon.ggg2014.orleans01.R1, 2019.

Wennberg, P. O., Wunch, D., Roehl, C. M., Blavier, J.-F., Toon, G. C., and Allen, N. T.: TCCON data from Caltech (US), Release GGG2014R1. TCCON data archive, hosted by CaltechDATA, https://doi.org/10.14291/tccon.ggg2014.pasadena01.R1/1182415, 2015.

Wennberg, P. O., Wunch, D., Roehl, C. M., Blavier, J.-F., Toon, G. C., Allen, N. T., Dowell, P., Teske, K., Martin, C., and Martin, J.: TCCON data from Lamont (US), Release GGG2014R1. TCCON data archive, hosted by CaltechDATA, https://doi.org/10.14291/tccon.ggg2014.lamont01.R1/1255070, 2016.

Wennberg, P. O., Roehl, C. M., Wunch, D., Toon, G. C., Blavier, J.-F., Washenfelder, R., Keppel-Aleks, G., Allen, N. T., and Ayers, J.: TCCON data from Park Falls (US), Release GGG2014R1. TCCON data archive, hosted by CaltechDATA, https://doi.org/10.14291/tccon.ggg2014.parkfalls01.R1, 2017.

Worden, J. R., Bloom, A. A., Pandey, S., Jiang, Z., Worden, H. M., Walter, T. W., Houweling, S., and Röckmann, T.: Reduced biomass burning emissions reconcile conflicting estimates of the post-2006 atmospheric methane budget, Nat. Commun., 8, 2227, https://doi.org/10.1038/s41467-017-02246-0, 2017.

Wu, L., Hasekamp, O., Hu, H., Landgraf, J., Butz, A., aan de Brugh, J., Aben, I., Pollard, D. F., Griffith, D. W. T., Feist, D. G., Koshelev, D., Hase, F., Toon, G. C., Ohyama, H., Morino, I., Notholt, J., Shiomi, K., Iraci, L., Schneider, M., de Mazière, M., Sussmann, R., Kivi, R., Warneke, T., Goo, T.-Y., and Té, Y.: Carbon dioxide retrieval from OCO-2 satellite observations using the RemoTeC algorithm and validation with TCCON measurements, Atmos. Meas. Tech., 11, 3111-3130, https://doi.org/10.5194/amt-11-3111-2018, 2018.

Wu, L., Aben, I., Hasekamp, O. P., and Buchwitz, M.: Product Quality Assessment Report (PQAR) - ANNEX B for products CO2_GOS_ SRFP, CH4_GOS_SRFP (v2.3.8, 2009-2018), Technical Report Copernicus Climate Change Service (C3S), version 3.1, 03-11-2019, 36 pp., available at: http://www.iup.uni-bremen.de/carbon_ghg/docs/C3S/CDR3_ 2003-2018/PQAR/C3S_D312b_Lot2.2.3.2-v1.0_PQAR-GHG_ ANNEX-B_v3.1.pdf (last access: 10 January 2020), 2019.
Wunch, D., Toon, G. C., Wennberg, P. O., Wofsy, S. C., Stephens, B. B., Fischer, M. L., Uchino, O., Abshire, J. B., Bernath, P., Biraud, S. C., Blavier, J.-F. L., Boone, C., Bowman, K. P., Browell, E. V., Campos, T., Connor, B. J., Daube, B. C., Deutscher, N. M., Diao, M., Elkins, J. W., Gerbig, C., Gottlieb, E., Griffith, D. W. T., Hurst, D. F., Jiménez, R., Keppel-Aleks, G., Kort, E. A., Macatangay, R., Machida, T., Matsueda, H., Moore, F., Morino, I., Park, S., Robinson, J., Roehl, C. M., Sawa, Y., Sherlock, V., Sweeney, C., Tanaka, T., and Zondlo, M. A.: Calibration of the Total Carbon Column Observing Network using aircraft profile data, Atmos. Meas. Tech., 3, 1351-1362, https://doi.org/10.5194/amt-3-1351-2010, 2010.

Wunch, D., Toon, G. C., Blavier, J.-F. L., Washenfelder, R. A., Notholt, J., Connor, B. J., Griffith, D. W. T., Sherlock, V., and Wennberg, P. O.: The Total Carbon Column Observing Network, Philos. T. R. Soc. A, 369, 2087-2112, https://doi.org/10.1098/rsta.2010.0240, 2011.

Wunch, D., Mendonca, J., Colebatch, O., Allen, N. T., Blavier, 5 J.-F., Roche, S., Hedelius, J., Neufeld, G., Springett, S., Worthy, D., Kessler, R., and Strong, K.: TCCON data from East Trout Lake, SK (CA), Release GGG2014.R1. TCCON data archive, hosted by CaltechDATA, https://doi.org/10.14291/tccon.ggg2014.easttroutlake01.R1, 2018.

Yin, Y., Ciais, P., Chevallier, F., Li, W., Bastos, A., Piao, S., Wang, T., and Liu, H.: Changes in the response of the Northern Hemisphere carbon uptake to temperature over the last three decades, Geophys. Res. Lett., 45, 4371-4380, https://doi.org/10.1029/2018GL077316, 2018.

Yoshida, Y., Kikuchi, N., Morino, I., Uchino, O., Oshchepkov, S., Bril, A., Saeki, T., Schutgens, N., Toon, G. C., Wunch, D., Roehl, C. M., Wennberg, P. O., Griffith, D. W. T., Deutscher, N. M., Warneke, T., Notholt, J., Robinson, J., Sherlock, V., Connor, B., Rettinger, M., Sussmann, R., Ahonen, P., Heikkinen, P., Kyrö, E., Mendonca, J., Strong, K., Hase, F., Dohe, S., and Yokota, T.: Improvement of the retrieval algorithm for GOSAT SWIR $\mathrm{XCO}_{2}$ and $\mathrm{XCH}_{4}$ and their validation using TCCON data, Atmos. Meas. Tech., 6, 1533-1547, https://doi.org/10.5194/amt-61533-2013, 2013. 